\title{
Balanced Scorecard Based Performance Analysis of Accreditation for Engineering Education
}

\author{
Yonghan Ju, So Young Sohn*, Jinsook Ahn, Jin Young Choi \\ Department of Information \& Industrial Engineering, Yonsei University, Seoul, Korea
}

(Received: February 20, 2014 / Revised: March 4, 2014 / Accepted: March 4, 2014)

\begin{abstract}
The number of students graduating from accredited programs has been increasing annually since the first students graduated from accredited engineering programs in Korean universities in 2004. In this paper, we evaluate the effect of engineering education accreditation by the Accreditation Board for Engineering Education of Korea (ABEEK). We developed performance evaluation indices based on the balanced scorecard concept and applied the proposed indicators to graduates, faculty, and industry employers to see if there are significant differences between accredited and non-accredited groups. Overall, regardless of survey object, engineering education accreditation was perceived to contribute to the elevation of engineering and science and the level of national growth. However, the differences between accredited and non-accredited groups for some key performance indicators were statistically insignificant. The results of this paper are expected to provide crucial feedback information for the improvement of engineering education accreditation in Korea.
\end{abstract}

Keywords: ABEEK, Engineering Education, Accreditation, Performance, BSC

* Corresponding Author, E-mail: sohns@yonsei.ac.kr

\section{INTRODUCTION}

Science and technology are the key elements contributing to global competitiveness in the 21 st century. Engineering, in particular, is a crucial component of advances in science and technology (Geiger, 1990; Sohn and $\mathrm{Ju}, 2010 \mathrm{a}$ ). The striking change in the global status of Korea is fundamentally based on the development of its engineering capabilities. Engineering is a critical component of Korean industries and plays a core role in advancing the technical and scientific knowledge of those industries. Due to the increase in the importance of engineering, additional focus has been placed on engineering education in Korea, and the majority of universities in Korea have begun to adopt engineering accreditation.

In 1999, the Accreditation Board for Engineering Education of Korea (ABEEK) was established to improve engineering education. ABEEK has concentrated its efforts on fostering engineering education and promoting qualified engineers through accreditation and consultation. Since accreditation was implemented in 2000, 604 programs in 101 universities have been accredited by 2013. As the social and national roles of ABEEK grow, the accreditation performance of engineering education has become a concern. Especially, society wants to know if accredited students have superior knowledge and ability compared to non-accredited students. In addition, in order to compare two groups, we need to set specific indicators and their relationship.

In this paper, we propose a framework for the performance evaluation of engineering education accreditation using the balanced scorecard (BSC) concept. According to Kaplan and Norton (1992, 2001a, 2001b, 2001c, 2004, 2013), the BSC contains a diverse set of performance measures spanning financial performance, customer relations, internal business processes, and the organization's learning and growth activities. Since Kap- 
lan and Norton suggested the general BSC model, many studies have used those four perspectives, or modified versions, in their BSCs. Generally, the BSC has been used to manage the performance of business (Carman, 2007; Perrin, 1998; Huang, 2009; Bobillo et al., 2009; Halbo et al., 2005; van Merode et al., 1999; Qin et al., 2013). However, Kaplan and Norton (2004) showed how BSC can be applied to education sector using the case of Fulton County School System. It has been further utilized in education fields (Umashanker and Dutta, 2007) to enhance both "institutional" and "quality" culture (Lawrence and Sharma, 2002).

ABET in United States has the longest history of the accreditation of engineering education, and one of the most representative performance analyses on accreditation of engineering programs was the Engineering Criteria 2000 (EC2000) study (Lattuca et al., 2006; Colbeck et al., 2000). EC2000 is new criteria for outcomes based accreditation. Lattuca et al. (2006, 2007) compared the effects of EC2000 before and after its implementation in terms of engineering programs' characteristics and student learning. In order to analyze the performance of EC2000, they collected data through the survey of graduates, deans, program chairs, faculty, and employers in terms of criterion 3(a-k) of engineering criteria 2000 of ABET. The results of this study show that the 2004 graduates (after EC2000) are better prepared than the 1994 graduates (before EC2000) in all nine factors reflecting the criterion $3(\mathrm{a}-\mathrm{k})$ learning outcomes:

1) applying math and science (criterion 3.a),

2) experimental skills (criterion 3.b),

3) applying engineering skills (criterion 3.k),

4) design and problem-solving skills (criterion 3.c, e),

5) communication skills (criterion 3.g),

6) group skills (criterion 3.d),

7) societal and global issues (criterion 3.h, j),

8) ethics and professionalism (criterion 3.f), and

9) life-long learning (criterion 3.i).

The largest differences between 1994 and 2004 graduates are in the awareness of societal and global issues (criterion 3.h, j) and the smallest difference is in graduates' abilities to apply mathematics and sciences (criterion 3.a). According to Lattuca et al. (2007), in the EC2000 areas where employers perceive the need for more attention to skill-building, such as teamwork, communication (criterion 3.d, g) and use of modern engineering tools (criterion 3.k), faculty and program chairs report the greatest increase in curricular emphasis. Furthermore, Lattuca et al. (2006) indicated that program chairs did not consider industry feedback as having a significant, independent influence on any changes at the program level, but they believe ABET has had a significant and independent influence on the curricular changes in their programs.

In this paper, we compare the performances of accredited programs to those non-accredited ones in Korea.
In addition, we consider the long-term impact, such as the percentage of students who go on to a higher stage of education, contribution to improvement in job performance, and advancement of engineering and science. In Korea, the ABEEK criteria (KEC2000) were constructed on the basis of EC2000 of ABET. We reorganized these criteria using the BSC concept and developed the performance evaluation indices to evaluate the performance of engineering education accreditation of Korea.

In the business field, the output-focused performance, such as financial measures, overlooks the importance of the organization's relationship with its environment (Butler et al., 1997; Chen, 2011; Ale Ebrahim et al., 2011; Wiratmadja et al., 2011). The same phenomenon occurs in engineering education accreditation area as well. EC2000 study evaluated the student learning outcome without proper explanation in regard to engineering education environment. On the contrary, in this paper, we consider the relationship among educational objectives, educational environment, learning and growth, and accreditation results. To overcome this limitation, we apply the BSC concept to engineering education accreditation. Since the BSC emphasizes the linkage of measurement to strategy (Kaplan and Norton, 1992) and provides a framework for managing the implementation of strategy while also allowing the strategy itself to evolve in response to changes in the company's environments (Kaplan and Norton, 1996), it is also possible to show the strategic linkage and cause-and-effect of components in engineering education environment by using BSC approach, in particular, strategy map. We propose a strategy map for the engineering education accreditation with performance evaluation indices.

The performance evaluation indices proposed with BSC approach in this paper include the quality and learning outcomes of students, educational objectives of program, program outcome and assessment, such as the criterion 3(a-k) of ABET, professional component, faculty, facilities $\&$ funds, and program criteria.

We consider students (graduates) as education recipients, professors as education providers, and companies as end education users. Three targeted groups compare accredited groups with non-accredited ones, in order to grasp significant differences between engineering education accreditation programs and non-accreditation programs. Especially, following aspects are focused: students' leaning and growth, internal processes, program objectives, educational environment, and accreditation results with respect to output, outcome, and impact.

Our main research hypothesis is that there would be some aspects of engineering accreditation which are perceived to be ineffective in view of professors, graduates, and employers, which need some further improvements.

The organization of this paper is as follows. Section 2 explains the institutional backgrounds and the current status of engineering education accreditation of Korea. Section 3 reviews related studies. Section 4 in- 
troduces critical success factors (CSFs) and key performance indicators (KPIs) as well as strategy map based on the BSC. Section 5 presents the empirical results of the data obtained from the accredited and non-accredited groups. The last section summarizes the results of this study and suggests areas for further investigation.

\section{INSTITUTIONAL BACKGROUNDS}

In this section, we summarize two of the most representative engineering accreditation criteria, which are ABET of the United States and UK-SPEC of the UK, along with the criteria of ABEEK.

\subsection{Accreditation Criteria of ABET and UK-SPEC}

Accreditation in the United States dates back to 1932, and over the decades the tendency for accreditation criteria was to become more detailed and prescriptive. However there was a major change in direction when ABET introduced the current EC2000 as accreditation criteria, which focus primarily on student learning outcomes (Bullen and Silverstein, 2005; Stiles, 1968). The programs seeking accreditation by ABET should demonstrate clearly that the program meets the following criteria (Felder and Brent, 2003): a) an ability to apply knowledge of mathematics, science and engineering; b) an ability to design and conduct experiments, as well as to analyze and interpret data; c) an ability to design a system, component, or process to meet desired needs within realistic constraints, such as economic, environmental, social, political, ethical, health and safety, manufacturability, and sustainability; d) an ability to function on multi-disciplinary teams; e) an ability to identify, formulate, and solve engineering problems; f) an understanding of professional and ethical responsibilities g) an ability to communicate effectively; h) the broad education necessary to understand the impact of engineering solutions in a global, economic, environmental, and societal context i) a recognition of the need for, and an ability to engage in life-long learning $\mathrm{j}$ ) a knowledge of contemporary issues; and k) an ability to use the techniques, skills, and modern engineering tools necessary form engineering practice.

In the UK, Engineering Council of the United Kingdom (ECUK, 2007) sets and maintains the standards for the engineering profession and sets the overall requirements for accreditation. ECUK licenses professional engineering institutions (licensed members) to undertake the accreditation within these requirements - interpreting them as appropriate for their own sector of the profession - and maintains the registers of accredited or approved programs. Licensed members use the accreditation process to assess whether specific educational programs provide some or all of the underpinning knowledge, understanding and skills for eventual registration in a particular category. Under the United Kingdom Stan- dard for Professional Engineering Competence (UKSPEC), the decision whether to accredit a program will be made on the basis of the program delivering the learning outcomes which the licensed member has specified. The output standards for accredited engineering program will encompass two different categories of learning outcomes that are inter-related. One category will be general in nature, and will apply to all types of program. The second category will be more specific. The first category, general learning outcomes describe the overall nature of the program (Bull et al., 2009): 1) knowledge and understanding, 2) intellectual abilities, 3) practical skills, and 4) general transferable skills. The second category, specific learning outcomes have the following items: 1) underpinning science and mathematics, and associated engineering disciplines, 2) engineering analysis, 3) design, 4) economic, social and environmental context, and 5) engineering practice.

\subsection{Accreditation Criteria of ABEEK}

Since its founding in 1999, the ABEEK has strived to ensure the quality of educational programs in engineering and related disciplines, and to enhance the professional competence of the graduates of those programs in Korea.

ABEEK carries out a comprehensive process of accreditation to determine whether engineering institutions fulfill the educational objectives of their programs, and whether these institutions have a system of continuous quality improvement in place by measuring their own performance and making appropriate changes. ABEEK also provides advisory services to help institutions and programs achieve the following goals. First, ABEEK assures that the graduates of accredited programs are qualified to start their professional careers in engineering. Second, it assures that accredited programs meet accreditation criteria. Third, it promotes new and innovative methods in engineering education, provides guidelines for engineering programs, and offers consultation regarding these guidelines. Fourth, ABEEK fosters public recognition of the accredited programs.

ABEEK administers the accreditation process and establishes accreditation criteria that address program educational objectives, program outcomes and assessment, professional components, faculty members, facilities and funding, and the program criteria. These criteria are applied with due discretion to fully reflect specialization and differentiation among the programs seeking accreditation (www.abeek.or.kr).

The accreditation criteria are applied to engineering education at four-year universities or colleges. Accreditation encourages outcome-based education. In this study, criteria were divided into eight standards: program educational objectives, program outcomes and assessment, subject domains, students, faculty, educational environment, educational improvement, and program criteria.

The program outcomes and assessment category is 
especially important. Engineering programs must demonstrate that their students attain the following (ABEE, 2005): 1) the ability to apply the mathematics, science, and engineering knowledge; 2) the ability to design and conduct experiments, as well as to analyze and interpret data; 3) the ability to design a system, component, or process to meet the desired needs; 4 ) the ability to function in multi-disciplinary teams; 5) the ability to identity, formulate, and solve engineering problems; 6) an understanding of professional and ethical responsibilities; 7) the ability to communicate effectively; 8) a broad education which is necessary to understand the impact of engineering solutions in a global and societal context; 9) recognition of the need for, and an ability to engage in life-long learning; 10) knowledge of contemporary issues in the society, economy, environment, and law; 11) the ability to understand other cultures and engage in international collaboration; and 12) the ability to use the up-to-date techniques, skills, and engineering tools required of engineering professionals. Each program should have an assessment process with documented results. The results should take into account the need for continual improvement of the program. Outcomes are important to satisfying the institutional mission and program objectives.

\section{LITERATURE REVIEW}

We review some related study on performance analysis and variables that have been considered in numerous studies of engineering education.

\subsection{Performance Analysis}

There have been diverse efforts to propose a proper evaluating method for engineering programs or departments in order to measure the performance of them (Chen et al., 2009; Felder and Hadgraft, 2013; Johnson et al., 1999; Lee et al., 2008; Murphy et al., 2010; Politis and Siskos, 2004; Siskos et al., 2007; Sohn and Ju, 2010b; Sohn and Ju, 2011; Sohn and Kim, 2012; Stronge and Helm, 1992). One of most representative case studies concerning performance analysis in engineering programs was the EC2000 study commissioned by the Center for the Study of Higher Education at Pennsylvania State University; this study lasted for three and a half years (Lattuca et al., 2006). The goal of the EC2000 study was to assess the effects of the outcome-based accreditation conducted by the ABET on aspects of engineering change. ABET was established to serve the public by the promotion and advancement of engineering education, applied science, computing, engineering, and technology through the development of better educated and more qualified persons in their respective fields. ABET evaluates educational programs at engineering colleges and universities and focuses mainly on program accreditation rather than institutional or departmental accreditation using out- come-based criteria (Patil and Codner, 2007).

Strauss and Terenzini (2005) described the development and evaluation of practical and useful instruments for assessing the learning outcomes specified in EC2000's criterion 3. EC2000 includes curricular and instructional practices, institutional polices, faculty culture and attitudes, and the eleven (a-k) learning outcomes. These authors extracted 38 items related to the learning outcomes, and then composed the nine factors from the outcome items using principal components analysis.

Lattuca et al. (2007) explored whether EC2000 has had a measurable impact on engineering program curricula, and whether the curricular changes observed are aligned with employers' ratings of the abilities of new engineering hires. For this, they compared the changes in programs and courses reported by chairs and faculty with the assessments of new engineering hires reported by employers. They found that the changes reported for each program by the chair generally exceeded the changes reported collectively by the faculty for their particular focal courses. They also found that the interaction among industry, engineering education, and ABET continues, so that engineering programs are increasing emphasis on those areas of knowledge and skills that employers judge to be the least well developed in new engineering hires.

In addition to engineering education area, studies regarding performance analyses have been actively conducted in many places. The common characteristic is setting up performance indicators. Porter et al. (2006) suggested a systematic model of innovation for science, technology, engineering, and mathematics (STEM) education. The model consists of seven segments which are research, mediators, teachers, settings, learners, performance, and assessment. Each segment has some related factors, such as experiential knowledge, educational materials, teaching knowledge, classroom, immediate learning, long-term learning, and the others. The model suggests that higher educational innovation in research universities is severely disadvantaged in many regards, and it also suggests a number of organizational and structural factors that must be addressed to bolster the prospects of educational improvement at research universities.

Sohn et al. (2007) evaluated the performance of financial support for R\&D in science and technology for SMEs. They developed indicators in terms of input, output, and environmental factors, and estimated the performance of R\&D fund recipients. They utilized Malcolm Baldrige National Quality Award (MBNQA) criteria in developing a model for assessing the R\&D performances.

In order to measure college students' perspectives towards engineering, Li et al. (2008) surveyed about 26 questions and conducted a factor analysis to obtain 4 factors, such as intrinsic value, cost value, individual utility value, and societal utility value.

Roach and Elliott (2006) investigated the influence of assess to general education curriculum on alternate 
assessment performance of students with significant cognitive disabilities. For this, the authors used Wisconsin Alternate Assessment, such as reading, language arts/ writing, mathematics, social studies, and science.

Development of indicators is an important process in performance analysis. We set up the performance indicators for accreditation based on KEC2005, which is the updated version of KEC2000.

\subsection{Balanced Scorecard}

It is evident that the BSC has been widely adopted in the business sector. Lately, it is applied to education sector (Umashanker and Dutta, 2007; Vogt, 2001). Sutherland (2000) reported that the Rossier School of Education at University of Southern California adopted the BSC to assess its academic program and planning process. Chen et al. (2006) studied the performance evaluation of higher education using the BSC. The purpose of their research was to examine whether the BSC can be used for performance evaluation of higher education as a strategic management tool. From the study, they found that both BSC and other management systems must be supported by senior supervisors and the outcome of implementation is promising and successful. In addition, the authors insisted that quantified performance measure indicators (PMIs) must be established in a specific and simple manner that allows all staff members to understand the orientation of the BSC in fulfilling their daily tasks, in order to evaluate progress and performance of higher education. Lee et al. (2000) investigated strategy formulation framework for vocational education. The proposed framework integrates three widely used business management strategic tools together with the education criteria 1999 adopted from the MBNQA for strategy development in vocational education. The methodology of their proposed framework was to conjoin the strengths, weakness, opportunities, threats (SWOT) matrix with the BSC, identifying the four CSFs. Lee and Walsh (2004) studied quality in early childhood programs. The authors used multiple methods, such as documents analysis, a survey questionnaire sent to programs evaluation and interview with early childhood practitioners. They mentioned that good evaluation should start with an in-depth understanding of the programs and open discussion about program quality and underlying values.

According to Kaplan and Norton (1992, 2001a, 2001b, 2001c, 2004), the BSC contains a diverse set of performance measures spanning financial performance, customer relations, internal business processes, and the organization's learning and growth activities. Since Kaplan and Norton suggested the general BSC model, many studies have used those four perspectives, or modified versions, in their BSCs. Olve et al. (1999) readjusted four perspectives for applied public section.

\section{PERFORMANCE ANALYSIS OF ACCREDITATION}

\subsection{Framework}

We propose a framework of performance analysis of engineering education accreditation based on BSC. We first introduce CSFs and KPIs which vary according to whether they are being applied to graduates, faculty, and industries, with several of the KPIs being common among these groups.

In the proposed BSC model to evaluate the performance of engineering accreditation, we define the following five perspectives: educational objectives and standards, internal processes, educational environment, learning and growth, and accreditation results. These perspectives were largely captured by the accreditation criteria of KEC2005 modified from KEC2000 which is the Korean version of EC2000. CSFs of these five aspects of Table 1 reflect KEC2005

We analyze both subjective and objective performances of accreditation. For this, the KPIs are set up in terms of qualitative and quantitative groups to represent both subjective and objective performances respectively, and all KPIs are investigated separately for individual target group in Table 1.

Qualitative indices are investigated in terms of a 7point Likert scale, higher number representing better performance while quantitative indices are adjusted to fit the scale as introduced in Table 1. For instance, percentage of employment and percentage of students who go on to a higher stage of education are rescaled form 0 to 10 representing $10 \%$ for $100 \%$.

Figure 1 presents the overall strategy map based on Table 1. Strategy map is developed by the members of ABEEK committee during November 2007 to October 2008 that is based on KEC 2005. The proposed strategy map consists of hierarchical concept of engineering education process. Especially, this strategy map describes the causal chains between the CSFs, such as reflection of industry requirements, graduate standards, curriculum, and so on. For example, "graduate standards" can be affected by "reflection of industry requirements", and this CSF affects "curriculum" and "student guidance and counseling." In the strategic map, "program outcomes and assessment" is the central role of causal chains because this CSF is the final destination of the paths including CSFs from the "educational objectives and standards" to "educational environment" perspectives, and the linkage to connect these perspectives to "accreditation results" perspective. The overall strategy map can be specified by each group, such as graduate group and faculty group. The industry group, however, cannot be specified into its own strategy map because the industry does not directly participate in the engineering education process. The strategy map of each group will be discussed later. 
Table 1. CSFs and KPIs for performance analysis of engineering accreditation

\begin{tabular}{|c|c|c|c|c|c|}
\hline \multirow{2}{*}{ Perspectives } & \multirow{2}{*}{ CSF } & \multicolumn{3}{|c|}{ KPI } & \multirow{2}{*}{ Scale } \\
\hline & & Quantitative indices & Qualitative indices & Survey target & \\
\hline \multirow{8}{*}{$\begin{array}{l}\text { Educational } \\
\text { objectives } \\
\text { and } \\
\text { standards }\end{array}$} & \multirow{7}{*}{$\begin{array}{l}\text { Reflection } \\
\text { of industry } \\
\text { requirements }\end{array}$} & & $\begin{array}{l}\text { Level of reflection of industry } \\
\text { requirements }\end{array}$ & $\begin{array}{c}\text { Graduate, } \\
\text { Faculty }\end{array}$ & 7-point \\
\hline & & & Level of fundamental knowledge & Industry & 7-point \\
\hline & & & Level of expert knowledge & Industry & 7-point \\
\hline & & & Ability to use equipment & Industry & 7-point \\
\hline & & & Technical planning and management & Industry & 7-point \\
\hline & & & Level of quality control knowledge & Industry & 7-point \\
\hline & & & Problem solving ability & Industry & 7-point \\
\hline & $\begin{array}{l}\text { Graduate } \\
\text { standards }\end{array}$ & & Communication and teamwork ability & Industry & 7-point \\
\hline \multirow{10}{*}{$\begin{array}{l}\text { Internal } \\
\text { processes }\end{array}$} & \multirow{4}{*}{ Curriculum } & & Adequacy of graduate standards & $\begin{array}{l}\text { Graduate, } \\
\text { Faculty }\end{array}$ & 7-point \\
\hline & & $\begin{array}{l}\text { Completion of more than } 30 \text { credits in } \\
\text { mathematics/science/computer }\end{array}$ & & Graduate & Yes/No \\
\hline & & $\begin{array}{l}\text { Completion of more than } 60 \text { credits in } \\
\text { major subjects }\end{array}$ & & Graduate & Yes/No \\
\hline & & $\begin{array}{l}\text { Completion of more than } 18 \text { credits in } \\
\text { design subjects }\end{array}$ & & Graduate & Yes/No \\
\hline & \multirow{6}{*}{$\begin{array}{l}\text { Student guidance } \\
\text { and counseling }\end{array}$} & $\begin{array}{l}\text { Completion of more than } 18 \text { credits in } \\
\text { cultural subjects }\end{array}$ & & Graduate & Yes/No \\
\hline & & & Adequacy of curriculum organization & $\begin{array}{l}\text { Graduate, } \\
\text { Faculty }\end{array}$ & 7-point \\
\hline & & Counseling or non-counseling & & Graduate & Yes/No \\
\hline & & Number of counselors & & Graduate & persons \\
\hline & & & Counseling satisfaction & Graduate & 7-point \\
\hline & & & Adequacy of administrative performance & $\begin{array}{l}\text { Graduate, } \\
\text { Faculty }\end{array}$ & 7-point \\
\hline \multirow{13}{*}{$\begin{array}{l}\text { Educational } \\
\text { environment }\end{array}$} & \multirow{5}{*}{$\begin{array}{l}\text { Facilities } \\
\text { and funds }\end{array}$} & & $\begin{array}{l}\text { Qualification and ability of teaching } \\
\text { assistants }\end{array}$ & $\begin{array}{l}\text { Graduate, } \\
\text { Faculty }\end{array}$ & 7-point \\
\hline & & Number of counseled students & & Faculty & Persons \\
\hline & & & $\begin{array}{l}\text { Adequacy of number of laboratories and } \\
\text { equipment/facilities }\end{array}$ & $\begin{array}{l}\text { Graduate, } \\
\text { Faculty }\end{array}$ & 7-point \\
\hline & & & $\begin{array}{l}\text { Laboratories and equipment/facilities } \\
\text { satisfaction }\end{array}$ & Graduate & 7-point \\
\hline & & & $\begin{array}{l}\text { Satisfaction in laboratories and equip- } \\
\text { ment/facilities condition }\end{array}$ & Faculty & 7-point \\
\hline & \multirow{5}{*}{$\begin{array}{l}\text { Qualifications } \\
\text { and ability } \\
\text { of faculty }\end{array}$} & & $\begin{array}{l}\text { Adequacy of estimates of purchasing } \\
\text { equipment/facilities and material for } \\
\text { experiments }\end{array}$ & Faculty & 7-point \\
\hline & & & $\begin{array}{l}\text { Adequacy of funds and administrative } \\
\text { support of department }\end{array}$ & Faculty & 7-point \\
\hline & & & Adequacy of administrative system & Graduate & 7-point \\
\hline & & & $\begin{array}{l}\text { Satisfaction of manner of lecturing (lec- } \\
\text { ture and practice) }\end{array}$ & Graduate & 7-point \\
\hline & & Years of lecturing & & Faculty & Years \\
\hline & \multirow{3}{*}{$\begin{array}{l}\text { Number of } \\
\text { faculty members }\end{array}$} & $\begin{array}{l}\text { Average number of supported } \\
\text { projects per year }\end{array}$ & & Faculty & Occurrence \\
\hline & & & Level of teaching ability & Graduate & 7-point \\
\hline & & & $\begin{array}{l}\text { Level of reflection of course evaluation } \\
\text { results }\end{array}$ & $\begin{array}{l}\text { Graduate, } \\
\text { Faculty }\end{array}$ & 7-point \\
\hline \multirow[t]{3}{*}{$\begin{array}{l}\text { Learning } \\
\text { and growth }\end{array}$} & \multirow{3}{*}{$\begin{array}{l}\text { Program } \\
\text { outcomes and } \\
\text { assessment }\end{array}$} & $\begin{array}{l}\text { Number of faculty members in the } \\
\text { program }\end{array}$ & & $\begin{array}{l}\text { Graduate, } \\
\text { Faculty }\end{array}$ & Persons \\
\hline & & Department personnel & & $\begin{array}{l}\text { Graduate, } \\
\text { Faculty }\end{array}$ & Persons \\
\hline & & Class hours per week & & Faculty & Hours \\
\hline
\end{tabular}




\begin{tabular}{|c|c|c|c|c|c|}
\hline & & & and engineering science knowledge & Faculty, Industry & \\
\hline & & & Ability to interpret and analyze data & $\begin{array}{c}\text { Graduate, } \\
\text { Faculty, Industry }\end{array}$ & 7-point \\
\hline & & & $\begin{array}{l}\text { Ability to design systems, components, } \\
\text { and processes }\end{array}$ & $\begin{array}{c}\text { Graduate, } \\
\text { Faculty, Industry }\end{array}$ & 7-point \\
\hline & & & $\begin{array}{l}\text { Ability to identify, formulate, and solve } \\
\text { engineering problems }\end{array}$ & $\begin{array}{c}\text { Graduate, } \\
\text { Faculty, Industry }\end{array}$ & 7-point \\
\hline & & & $\begin{array}{l}\text { Ability to use up-to-date techniques, } \\
\text { skills, and engineering tools }\end{array}$ & $\begin{array}{c}\text { Graduate, } \\
\text { Faculty, Industry }\end{array}$ & 7-point \\
\hline & & & $\begin{array}{l}\text { Ability to function in multi-disciplinary } \\
\text { teams }\end{array}$ & $\begin{array}{c}\text { Graduate, } \\
\text { Faculty, Industry }\end{array}$ & 7-point \\
\hline & & & Ability to communicate effectively & $\begin{array}{c}\text { Graduate, } \\
\text { Faculty, Industry }\end{array}$ & 7-point \\
\hline & & & $\begin{array}{l}\text { Recognition of the need for, and an } \\
\text { ability to engage in life-long learning }\end{array}$ & $\begin{array}{c}\text { Graduate, } \\
\text { Faculty, Industry }\end{array}$ & 7-point \\
\hline & & & $\begin{array}{l}\text { Ability to understand the impact of } \\
\text { engineering solutions in a global and } \\
\text { social context }\end{array}$ & $\begin{array}{l}\text { Graduate, } \\
\text { Faculty, Industry }\end{array}$ & 7-point \\
\hline & & & $\begin{array}{l}\text { Knowledge of contemporary issues in } \\
\text { the society, economy, environment, and } \\
\text { law }\end{array}$ & $\begin{array}{l}\text { Graduate, } \\
\text { Faculty, Industry }\end{array}$ & 7-point \\
\hline & \multirow{7}{*}{$\begin{array}{l}\text { Program and } \\
\text { educational } \\
\text { improvement }\end{array}$} & & $\begin{array}{l}\text { Understanding of professional and ethi- } \\
\text { cal responsibilities }\end{array}$ & $\begin{array}{c}\text { Graduate, } \\
\text { Faculty, Industry }\end{array}$ & 7-point \\
\hline & & & $\begin{array}{l}\text { Ability to understand other cultures and } \\
\text { engage in international collaboration }\end{array}$ & $\begin{array}{c}\text { Graduate, } \\
\text { Faculty, Industry }\end{array}$ & 7-point \\
\hline & & & Ability to think creatively & $\begin{array}{c}\text { Graduate, } \\
\text { Faculty, Industry }\end{array}$ & 7-point \\
\hline & & & Level of self-enrichment & $\begin{array}{l}\text { Graduate, } \\
\text { Industry }\end{array}$ & 7-point \\
\hline & & $\begin{array}{l}\text { Proportion of improvement over the } \\
\text { previous evaluation results }\end{array}$ & & Faculty & $\begin{array}{c}\text { Percentage } \\
\text { (10-point) }\end{array}$ \\
\hline & & & $\begin{array}{l}\text { Consistency of continuous quality } \\
\text { improvement (CQI) system }\end{array}$ & Faculty & 7-point \\
\hline & & $\begin{array}{l}\text { Number of internal program evalua- } \\
\text { tions }\end{array}$ & & Faculty & Occurrence \\
\hline \multirow{11}{*}{$\begin{array}{l}\text { Accreditation } \\
\text { results }\end{array}$} & \multirow{3}{*}{ Output } & $\begin{array}{l}\text { Number of external program evalua- } \\
\text { tions }\end{array}$ & & Faculty & Occurrence \\
\hline & & $\begin{array}{l}\text { Number of evaluations of achieve- } \\
\text { ment of educational objectives }\end{array}$ & & Faculty & Occurrence \\
\hline & & & $\begin{array}{l}\text { Level of internal program compared with } \\
\text { external program }\end{array}$ & Faculty & 7-point \\
\hline & & & $\begin{array}{l}\text { Level of data and documents manage- } \\
\text { ment }\end{array}$ & Faculty & 7-point \\
\hline & Outcom & Percentage of employment & & $\begin{array}{l}\text { Graduate, } \\
\text { Faculty }\end{array}$ & $\begin{array}{l}\text { Percentage } \\
\text { (10-point) }\end{array}$ \\
\hline & Uutcome & $\begin{array}{l}\text { Percentage of students who go on to a } \\
\text { higher stage of education }\end{array}$ & & $\begin{array}{l}\text { Graduate, } \\
\text { Faculty }\end{array}$ & $\begin{array}{c}\text { Percentage } \\
\text { (10-point) }\end{array}$ \\
\hline & & & $\begin{array}{l}\text { Educational program's effect on the con- } \\
\text { tribution of new employees }\end{array}$ & Industry & 7-point \\
\hline & & & Improvement in departmental awareness & Faculty & 7-point \\
\hline & & & Level of training expertise & Graduate, Faculty & 7-point \\
\hline & Impact & & $\begin{array}{l}\text { Improvement in level of curriculum and } \\
\text { educational program }\end{array}$ & Graduate, Faculty & 7-point \\
\hline & & & $\begin{array}{l}\text { Level of increment of research interac- } \\
\text { tion with industry }\end{array}$ & Faculty & 7-point \\
\hline
\end{tabular}

CSF: critical success factor, KPI: key performance indicator. 


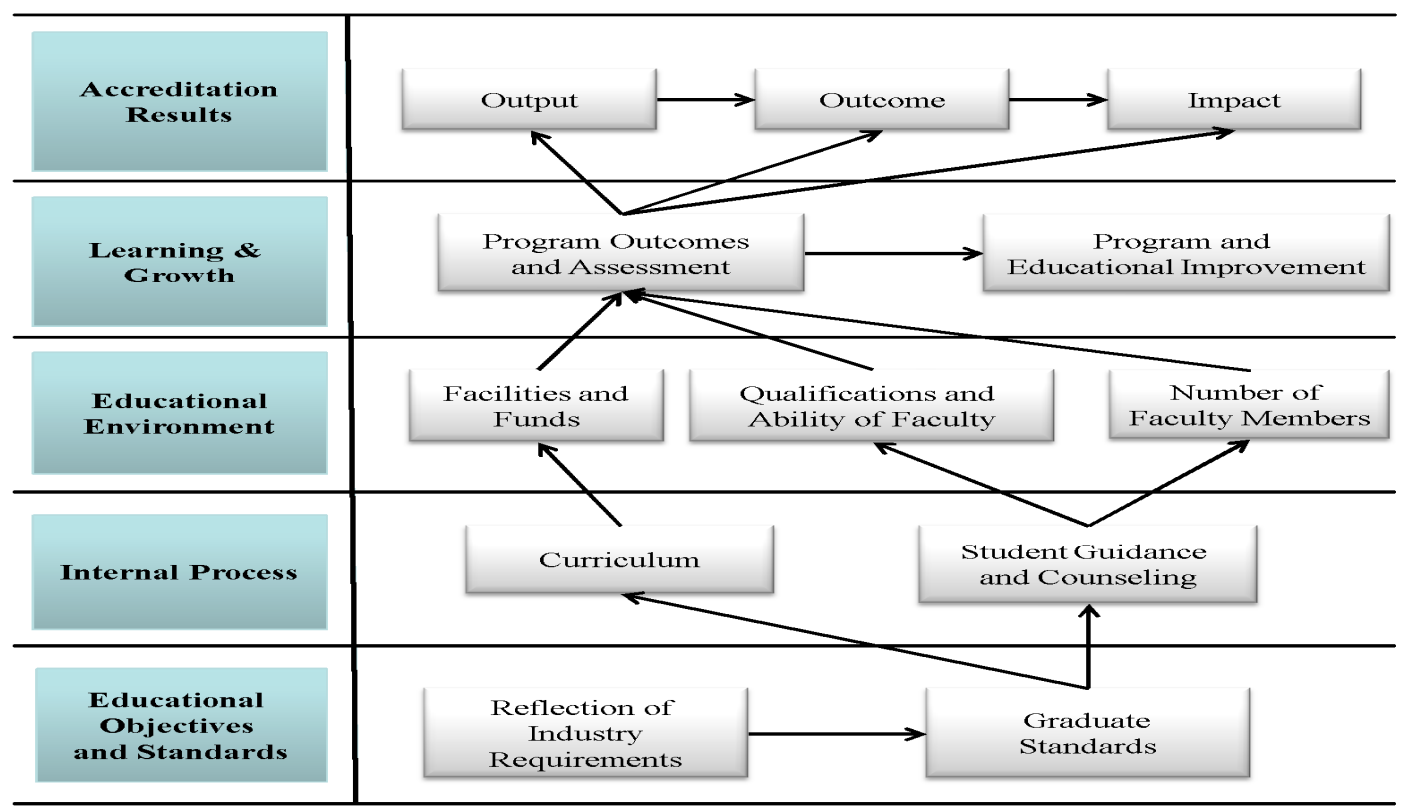

Figure 1. Overall strategic map.

From the preceding research, we confirmed that BSC concept can be used performance analysis of accreditation for engineering education. The BSC has been used effectively in this research because it offers quantitative and qualitative information. We investigated the effect of engineering accreditation using the following three hypotheses based on BSC concept:

Hypothesis 1: The expected KPI values of graduates would not differ between accredited and non accredited programs.

Hypothesis 2: The expected KPI values of professors would not differ between accredited and non accredited programs.

Hypothesis 3: The expected KPI values of employers would not differ between accredited and non accredited programs.

For the test of these hypotheses, we surveyed corresponding three groups.

\subsection{Survey Data}

A survey was distributed to industry employers, graduates, and faculty members from accredited and nonaccredited programs via a professional survey agency during the two weeks of August 11-22, and August 11 to September 21, 2008. Some examples of the survey questions are shown in Appendix A.

In order to collect the data of graduated from accredited programs; we conducted random survey that is conducted by professional survey agency. Total 2,110 graduated who have graduated from accredited program after 2004, which was the first year students graduated from accredited engineering programs in Korean universities. In a population, the agency has set up the number of sample population that is about 100 graduates. Through Web based survey and phone call survey, 103 graduates were responded to survey.

Thus total respondents for accredited graduates' survey were 103 . Among them $76 \%$ are male. At the same time, the survey agency collected 100 responses for nonaccredited program graduates: 58 responded from telephone survey, 42 responded from field surveys. Of 100 non-accredited program respondents, $97 \%$ are male. The proportion of considered engineering disciplines of graduates' population show that the sample has a plausible representativeness: architectural engineering (5\%), mechanical engineering $(23 \%)$, industrial engineering $(2 \%)$, material engineering (6\%), electrical engineering $(26 \%)$, computer engineering (15\%), environmental engineering $(3 \%)$, chemical engineering $(3 \%)$, civil engineering $(8 \%)$, and etc. $(9 \%)$.

In the case of both faculty and employer respondents, we tried to get similar size of sample to the number of graduates respondents. We obtained a total of 110 responses for faculty survey: computer engineering (31\%), mechanical engineering (18\%), electrical engineering $(12 \%)$, chemical engineering (11\%), architectural engineering $(7 \%)$, industrial engineering (7\%), environmental engineering $(5 \%)$, materials engineering $(4 \%)$, civil engineering $(3 \%)$, biological engineering $(1 \%)$, and textile engineering $(1 \%)$.

The agency also performed industry survey to collect employer's responses. Through telephone survey, the agency gathered 100 sample data of industry employers: the target respondents were from selected companies listed in the Korea Securities Dealers Automated 
Quotations (KOSDAQ) which have employees who graduated from both accredited and non accredited programs. The respondent industries consist of construction (24\%), electricity (16\%), shipbuilding $(12 \%)$, motor $(10 \%)$, mechanic $(10 \%)$, metal $(6 \%)$, semiconductor $(5 \%)$, aircraft $(5 \%)$, energy $(3 \%)$, railway ( $2 \%)$, appliances $(2 \%)$, pharmaceutical (1\%), and other industries (4\%).

Consequently, we obtained 103 accredited program graduates, 100 non-accredited program graduates, 110 faculty members, and 100 industry employers' data. Using these data, we conducted the performance evaluation of engineering education accreditation.

\section{EMPIRICAL PERFORMANCE EVALUATION OF ACCREDITATION}

In this section, we test our hypotheses on the performance comparison of engineering education accreditation by applying the proposed indicators to graduates, faculty members, and industry employers to see if there are significant differences between accredited and nonaccredited engineering programs.

\subsection{Graduates}

To test Hypothesis 1, we begin with the null hypothesis that the expected KPI values of graduates would not differ between accredited and non-accredited programs. To test this hypothesis, we conducted t-test. The results are shown in Table 2.

At a significance level of 5\%, all KPIs showed a significant difference between accredited and non-accredited programs except for the frequency of counseling experienced, number of faculty members, percentage of employment, and percentage of students who go on to a higher stage of education.

These results showed that the engineering education accreditation policy is effective too graduates in general. Especially, accredited programs have higher score than non-accredited programs about all KPIs of 'program outcomes and assessment'. The largest KPI difference between accredited and non-accredited programs was found in adequacy of graduate standards. Also, accredited programs have a higher score than non-accredited programs in terms of outcome and impact of CSF. But, output has insignificant difference between accredited and non-accredited programs. Such a result means that accreditation policy needs to be supplemented in terms of output.

To obtain additional information from graduate survey, such as differences in the counseling experience or the required credits for specific subjects of two groups, we conducted a chi-square test additionally. In this chi-square test, the null hypothesis is the same as the one used with the previous t-test. The chi-square and t-test are used to analyze of proportions, continuous normal random variables, respectively (Murphy et al.,
2010). The results of chi-square test are given in Table 3.

The chi-square test results indicate that two KPIs (completion of more than 60 credits in major subjects, and completion of more than 18 credits in cultural subjects) did not show a significant difference at a level of $5 \%$. However, accredited graduates have more credits completed in mathematics/science/computer and design subjects.

Figure 2 shows the strategy map for graduates. The CSF "program and educational improvement" was not included in this strategic map because graduates do not concern this CSF (refer to Figure 1 for the overall strategy map). The circles displayed in Figure 2 indicate the CSFs which have at least one insignificant KPI. From this, we found that the "internal process" is the weakest in the graduates' perspectives, and suggest that the "curriculum", "student guidance and counseling", "number of faculty members" and "output" should be improved to gain better accreditation effects in graduates' perspectives.

\subsection{Faculty}

In the faculty survey, we classified accreditation types as non-accredited, accreditation disapproved, accreditation evaluation reserved, accreditation evaluation in progress, preliminarily accredited, and accredited. The class "non-accredited" indicates that preparation is underway for engineering accreditation evaluation. "Accreditation disapproved" is the result of a failed accreditation evaluation. "Accreditation evaluation reserved" indicates a pending evaluation. "Accreditation evaluation in progress" indicates an on-going evaluation. "Preliminarily accredited" indicates an approved engineering program which does not have graduates yet. "Accredited" indicates an approved engineering program which has graduates. There were 33 programs in the nonaccredited class $(30 \%)$, three in the accreditation disapproved class $(3 \%)$, eight from the accreditation evaluation reserved class (7\%), 21 in the accreditation evaluation in progress class (19\%), 26 from the preliminarily accredited class $(24 \%)$, and 19 from the accredited class $(17 \%)$. We divided the five accreditation types into two groups: accredited (preliminarily accredited and accredited), and non-accredited (non-accredited, accreditation disapproved, accreditation evaluation reserved, and accreditation evaluation in progress).

Then we conducted a t-test to determine the significance of differences between the accredited and nonaccredited groups in the perspectives of professors. The null hypothesis is that the expected KPI of professors would not differ between accredited and non-accredited programs. The results of the t-test for faculty are shown in Table 4.

The results of the t-test in the Table 4 showed that two groups of professors evaluated that a large proportion of KPIs is not significantly different between the accredited and non-accredited groups. Only fourteen KPIs turned out to have significant difference at a level of $5 \%$. 
Table 2. The results of the t-tests for graduates

\begin{tabular}{|c|c|c|c|c|c|c|c|}
\hline \multirow{2}{*}{ CSF } & \multicolumn{2}{|r|}{ KPI } & \multirow{2}{*}{ Group } & \multirow{2}{*}{ Mean } & \multirow{2}{*}{ Difference } & \multirow{2}{*}{$\mathrm{t}$} & \multirow{2}{*}{ p-value } \\
\hline & Quantitative indices & Qualitative indices & & & & & \\
\hline \multirow{2}{*}{$\begin{array}{l}\text { Reflection of } \\
\text { industry } \\
\text { requirements }\end{array}$} & & \multirow{2}{*}{ Level of reflection of industry requirements* } & Accredited & 5.19 & \multirow{2}{*}{0.91} & \multirow{2}{*}{5.03} & \multirow{2}{*}{$<0.000$} \\
\hline & & & Non-accredited & 4.28 & & & \\
\hline \multirow{2}{*}{$\begin{array}{l}\text { Graduate } \\
\text { standards }\end{array}$} & & \multirow{2}{*}{ Adequacy of graduate standards* } & Accredited & 5.52 & \multirow{2}{*}{1.13} & \multirow{2}{*}{6.30} & \multirow{2}{*}{$<0.0001$} \\
\hline & & & Non-accredited & 4.39 & & & \\
\hline \multirow{2}{*}{ Curriculum } & & \multirow{2}{*}{ Adequacy of curriculum organization* } & Accredited & 5.22 & 081 & 500 & $<00001$ \\
\hline & & & Non-accredited & 4.41 & 0.01 & 0.00 & 20.0001 \\
\hline & Number of counsel- & & Accredited & 2.23 & & & \\
\hline & ing experienced & & Non-accredited & 3.79 & $-1.5 /$ & -1.38 & $0.1 / 17$ \\
\hline & & Counseling satisfaction* & Accredited & 4.84 & 105 & 369 & 00003 \\
\hline $\begin{array}{l}\text { Student } \\
\text { guidance and }\end{array}$ & & "Counseinng sautstaction & Non-accredited & 3.78 & 1.05 & 3.09 & 0.0003 \\
\hline & & Adeguacy of administrative nerformance* & Accredited & 4.95 & 091 & 453 & $<0.0001$ \\
\hline & & 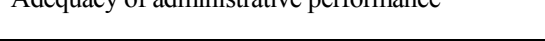 & Non-accredited & 4.04 & 0.91 & $4 . J 3$ & 0.0001 \\
\hline & & Qualifications and ability of teaching assistants* & Accredited & 4.92 & 0.59 & 3.10 & 0.0022 \\
\hline & & & Non-accredited & 4.33 & & & \\
\hline & & Adequacy of number of laboratories and equip- & Accredited & 4.74 & 0.44 & 2.13 & 0.0348 \\
\hline & & ment/facilities* & Non-accredited & 4.29 & 0.44 & & \\
\hline Facilities & & Laboratories and equipment/facilities satisfac- & Accredited & 4.67 & 0.42 & 202 & 0.0444 \\
\hline and finds & & tion* & Non-accredited & 4.25 & 0.42 & 2.02 & $0.04+44$ \\
\hline & & Adequacy of administrative system* & Accredited & 4.94 & 0.63 & 349 & 0.0006 \\
\hline & & 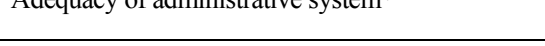 & Non-accredited & 4.31 & $0.0 J$ & 3.45 & 0.0000 \\
\hline & & Satisfaction in manner of lecturing (lecture and & Accredited & 5.34 & 0.93 & 568 & \\
\hline & & practice)* & Non-accredited & 4.41 & 0.93 & 5.08 & $<0.0001$ \\
\hline $\begin{array}{l}\text { Qualifications } \\
\text { and ability }\end{array}$ & & Level of teaching abilitv* & Accredited & 5.64 & 072 & 467 & $<0.0001$ \\
\hline of faculty & & Lever or teaching aominy & Non-accredited & 4.92 & 0.12 & 4.01 & 0.0001 \\
\hline & & Level of reflection of course evaluation results* & Accredited & 5.20 & 058 & 335 & 0001 \\
\hline & & 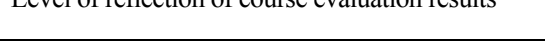 & Non-accredited & 4.63 & 0.00 & J.JJ & 0.001 \\
\hline Number & Number of faculty & & Accredited & 10.54 & & & \\
\hline $\begin{array}{l}\text { of faculty } \\
\text { numbers }\end{array}$ & members & & Non-accredited & 11.08 & -0.54 & -0.42 & 0.6758 \\
\hline Program out- & & Ability to apply mathematics, science, and & Accredited & 5.35 & 0.63 & 380 & 0.0002 \\
\hline $\begin{array}{c}\text { comes and as- } \\
\text { sessment }\end{array}$ & & engineering science knowledge* & Non-accredited & 4.72 & & & \\
\hline & & Ability to internret and analvze data* & Accredited & 5.27 & 060 & 374 & 00002 \\
\hline & & 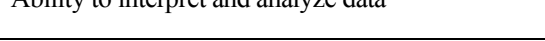 & Non-accredited & 4.67 & 0.00 & 0.14 & 0.0002 \\
\hline & & Ability to design systems, components, and & Accredited & 5.04 & 0.63 & 381 & 00002 \\
\hline & & processes* & Non-accredited & 4.41 & 0.05 & 3.01 & 0.0002 \\
\hline & & Ability to identify, formulate, and solve engineer- & Accredited & 5.33 & 0.81 & 5.04 & $<0.0001$ \\
\hline & & ing problems* & Non-accredited & 4.52 & 0.01 & & \\
\hline & & Ability to use up-to-date techniques, skills, & Accredited & 5.13 & 069 & 3.81 & 0.0002 \\
\hline & & and engineering tools* & Non-accredited & 4.44 & & & \\
\hline & & Ability to function in multi-disciplinary teams* & Accredited & 5.50 & 079 & 486 & $<0.0001$ \\
\hline & & 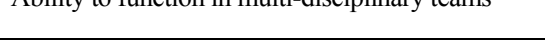 & Non-accredited & 4.71 & 0.13 & 4.00 & 0.0001 \\
\hline & & Ability to communicate effectively* & Accredited & 5.38 & 0.72 & 4.43 & $<0.0001$ \\
\hline & & Abinty to communicale enectivery. & Non-accredited & 4.66 & 0.12 & 4.43 & $<0.0001$ \\
\hline & & Recognition of the need for, and an ability & Accredited & 5.43 & 0.59 & 2.96 & 0.0035 \\
\hline & & to engage in life-long learning* & Non-accredited & 4.84 & 0.39 & 2.90 & 0.0033 \\
\hline & & Ability to understand the impact of engineering & Accredited & 5.12 & 0.62 & 339 & 0.0008 \\
\hline & & solutions in a global and social context* & Non-accredited & 4.50 & 0.02 & ( & 0.0000 \\
\hline & & Knowledge of contemporary issues in the society, & Accredited & 4.80 & 0.61 & 3.16 & 0.0018 \\
\hline & & economy, environment, and law* & Non-accredited & 4.19 & & & \\
\hline & & Understanding of professional and ethical re- & Accredited & 5.00 & 0.82 & 458 & $<0.0001$ \\
\hline & & sponsibilities* & Non-accredited & 4.18 & 0.02 & 4.50 & \\
\hline
\end{tabular}




\begin{tabular}{|c|c|c|c|c|c|c|c|}
\hline & & \multirow{2}{*}{$\begin{array}{l}\text { Ability to understand other cultures and engage in } \\
\text { international collaboration* }\end{array}$} & Accredited & 4.54 & \multirow{2}{*}{0.71} & \multirow{2}{*}{3.51} & \multirow{2}{*}{0.0006} \\
\hline & & & Non-accredited & 3.83 & & & \\
\hline & & \multirow{2}{*}{ Ability to think creatively* } & Accredited & 5.11 & \multirow{2}{*}{0.73} & \multirow{2}{*}{4.33} & \multirow{2}{*}{$<0.000$} \\
\hline & & & Non-accredited & 4.38 & & & \\
\hline & & \multirow{2}{*}{ Level of self-enrichment* } & Accredited & 5.48 & \multirow{2}{*}{0.78} & \multirow{2}{*}{4.58} & \multirow{2}{*}{$<0.000$} \\
\hline & & & Non-accredited & 4.70 & & & \\
\hline \multirow{4}{*}{ Output } & \multirow{2}{*}{$\begin{array}{l}\text { Percentage of em- } \\
\text { ployment }\end{array}$} & & Accredited & 7.11 & \multirow{2}{*}{0.29} & \multirow{2}{*}{1.13} & \multirow{2}{*}{0.2592} \\
\hline & & & Non-accredited & 6.82 & & & \\
\hline & \multirow{2}{*}{$\begin{array}{l}\text { Percentage of stu- } \\
\text { dents who go on to a } \\
\text { higher stage of edu- } \\
\text { cation }\end{array}$} & & Accredited & 4.26 & \multirow[b]{2}{*}{0.20} & \multirow[b]{2}{*}{0.50} & \multirow[b]{2}{*}{0.6193} \\
\hline & & & Non-accredited & 4.06 & & & \\
\hline \multirow{6}{*}{ Outcome } & \multirow{2}{*}{\multicolumn{2}{|c|}{ Level of training expertise* }} & Accredited & 5.10 & \multirow{2}{*}{0.82} & \multirow{2}{*}{5.33} & \multirow{2}{*}{$<0.0001$} \\
\hline & & & Non-accredited & 4.21 & & & \\
\hline & & \multirow{2}{*}{$\begin{array}{l}\text { Improvement level of curriculum and educational } \\
\text { program* }\end{array}$} & Accredited & 5.37 & \multirow{2}{*}{0.89} & \multirow{2}{*}{5.05} & \multirow{2}{*}{$<0.0001$} \\
\hline & & & Non-accredited & 4.55 & & & \\
\hline & & \multirow{2}{*}{ Elevation level of engineer's pride* } & Accredited & 5.41 & \multirow{2}{*}{0.87} & \multirow{2}{*}{5.15} & \multirow{2}{*}{$<0.0001$} \\
\hline & & & Non-accredited & 4.54 & & & \\
\hline & & & Accredited & 5.17 & 101 & & \\
\hline & & Contribution to the perception of engineering & Non-accredited & 4.16 & 1.01 & 5.43 & $<0.0001$ \\
\hline & & & Accredited & 4.92 & 0.62 & 321 & \\
\hline Impact & & Contribution to national growth* & Non-accredited & 4.30 & 0.62 & 3.21 & 0.0015 \\
\hline & & Advancement of engineering and science* & Accredited & 5.01 & 079 & 371 & 00003 \\
\hline & & Auvancentint or engintering and science & Non-accredited & 4.22 & 0.19 & 5.11 & 0.0005 \\
\hline
\end{tabular}

CSF: critical success factor, KPI: key performance indicator.

$* \mathrm{p}<0.05$.

Table 3. Results of the chi-square test for graduates

\begin{tabular}{|c|c|c|c|c|c|c|}
\hline CSF & \multicolumn{2}{|l|}{ KPI } & $\begin{array}{c}\text { Accredited or } \\
\text { Non-accredited } \\
\end{array}$ & $\mathrm{N}$ & $\chi^{2}$ & $\mathrm{p}$-value \\
\hline \multirow{4}{*}{$\begin{array}{c}\text { Student } \\
\text { guidance and } \\
\text { counseling }\end{array}$} & \multirow{4}{*}{\multicolumn{2}{|c|}{ Counseling or non-counseling* }} & \multirow{2}{*}{ Accredited } & 92 & \multirow{4}{*}{15.3811} & \multirow{4}{*}{$<.0001$} \\
\hline & & & & 9 & & \\
\hline & & & \multirow{2}{*}{ Non-accredited } & 69 & & \\
\hline & & & & 31 & & \\
\hline CSF & KPI & $\begin{array}{l}\text { Accredited or } \\
\text { Non-accredited }\end{array}$ & $\begin{array}{c}\text { Whether or not to } \\
\text { complete }\end{array}$ & $\mathrm{N}$ & $\chi^{2}$ & p-value \\
\hline \multirow{16}{*}{$\begin{array}{l}\text { Professional } \\
\text { component }\end{array}$} & \multirow{4}{*}{$\begin{array}{l}\text { More than } 30 \text { credits completed in } \\
\text { mathematics/science/computer* }\end{array}$} & \multirow{2}{*}{ Accredited } & yes & 97 & \multirow{4}{*}{13.7864} & \multirow{4}{*}{0.0002} \\
\hline & & & no & 0 & & \\
\hline & & \multirow{2}{*}{ Non-accredited } & yes & 85 & & \\
\hline & & & no & 13 & & \\
\hline & \multirow{4}{*}{$\begin{array}{l}\text { More than } 60 \text { credits completed in } \\
\text { major subjects }\end{array}$} & \multirow{2}{*}{ Accredited } & yes & 93 & \multirow{4}{*}{0.0009} & \multirow{4}{*}{0.9765} \\
\hline & & & no & 4 & & \\
\hline & & \multirow{2}{*}{ Non-accredited } & yes & 95 & & \\
\hline & & & no & 4 & & \\
\hline & \multirow{4}{*}{$\begin{array}{l}\text { More than } 18 \text { credits completed in } \\
\text { design subjects* }\end{array}$} & \multirow{2}{*}{ Accredited } & yes & 74 & \multirow{4}{*}{13.6107} & \multirow{4}{*}{0.0002} \\
\hline & & & no & 12 & & \\
\hline & & \multirow{2}{*}{ Non-accredited } & yes & 58 & & \\
\hline & & & no & 36 & & \\
\hline & \multirow{4}{*}{$\begin{array}{l}\text { More than } 18 \text { credits completed in } \\
\text { cultural subjects }\end{array}$} & \multirow{2}{*}{ Accredited } & yes & 88 & \multirow{4}{*}{2.1263} & \multirow{4}{*}{0.1448} \\
\hline & & & no & 5 & & \\
\hline & & \multirow{2}{*}{ Non-accredited } & yes & 87 & & \\
\hline & & & no & 11 & & \\
\hline
\end{tabular}

CSF: critical success factor, KPI: key performance indicator.

$* \mathrm{p}<0.05$. 
Table 4. The results of the t-test for faculty

\begin{tabular}{|c|c|c|c|c|c|c|c|}
\hline \multirow{2}{*}{ CSF } & \multicolumn{2}{|r|}{ KPI } & \multirow{2}{*}{ Group } & \multirow{2}{*}{ Mean } & \multirow{2}{*}{ Difference } & \multirow{2}{*}{$\mathrm{t}$} & \multirow{2}{*}{ p-value } \\
\hline & Quantitative indices & Qualitative indices & & & & & \\
\hline \multirow{2}{*}{$\begin{array}{l}\text { Reflection of } \\
\text { industry } \\
\text { requirements }\end{array}$} & & \multirow{2}{*}{ Level of reflection of industry requirements } & Accredited & 4.96 & \multirow{2}{*}{0.42} & \multirow{2}{*}{1.08} & \multirow{2}{*}{0.0745} \\
\hline & & & Non-accredited & 4.54 & & & \\
\hline \multirow{2}{*}{$\begin{array}{l}\text { Graduate } \\
\text { standards }\end{array}$} & & \multirow{2}{*}{ Adequacy of graduate standards* } & Accredited & 5.69 & \multirow{2}{*}{0.38} & \multirow{2}{*}{2.07} & \multirow{2}{*}{0.0409} \\
\hline & & & Non-accredited & 5.31 & & & \\
\hline \multirow{2}{*}{ Curriculum } & & \multirow{2}{*}{ Adequacy of curriculum organization } & Accredited & 5.51 & \multirow{2}{*}{0.2} & \multirow{2}{*}{1.18} & \multirow{2}{*}{0.2399} \\
\hline & & & Non-accredited & 5.31 & & & \\
\hline & & & Accredited & 3.87 & & & \\
\hline & & Adequacy of adminıstratıve performance & Non-accredited & 3.74 & 0.13 & 0.47 & 0.6409 \\
\hline $\begin{array}{c}\text { Student } \\
\text { guidance and }\end{array}$ & & & Accredited & 3.87 & & & \\
\hline $\begin{array}{l}\text { guidance and } \\
\text { counseling }\end{array}$ & & Qualifications and ability of teaching assistants & Non-accredited & 3.74 & 0.12 & 0.46 & 0.6493 \\
\hline & Number of counseled students & & Accredited & 4.40 & 430 & 134 & 01841 \\
\hline & 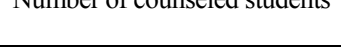 & & Non-accredited & 4.28 & -4.50 & -1.04 & $0.10+1$ \\
\hline & & Adequacy of laboratories and equip- & Accredited & 4.36 & -0.17 & -0.62 & 0.5355 \\
\hline & & ment/facilities & Non-accredited & 4.52 & $-0.1 /$ & -0.02 & 0.5335 \\
\hline & & & Accredited & 4.13 & & & 02814 \\
\hline Facilities & & Laboratory and equipment/facilities conditions & Non-accredited & 4.42 & -0.29 & -1.08 & 0.2814 \\
\hline and funds & & Adequacy of estimates of purchasing equip- & Accredited & 3.64 & -063 & -230 & 00234 \\
\hline & & ment/facilities and material for experiments* & Non-accredited & 4.28 & -0.05 & -2.50 & 0.020 \\
\hline & & Adequacy of funds and administrative support & Accredited & 3.47 & -0.40 & -158 & 01166 \\
\hline & & of department & Non-accredited & 3.86 & -0.40 & -1.50 & 0.1100 \\
\hline & Years of lecturing & & Accredited & 14.68 & 057 & 039 & 06086 \\
\hline & Years of lecturing & & Non-accredited & 14.11 & $0.5 \%$ & 0.39 & 0.6986 \\
\hline Qualifications & Average number of supported & & Accredited & 1.92 & & & \\
\hline $\begin{array}{l}\text { and ability of } \\
\text { faculty }\end{array}$ & projects per year & & Non-accredited & 1.84 & 0.09 & 0.6 & 0.7929 \\
\hline & & Level of reflection of course evaluation results & Accredited & 5.21 & 012 & 061 & 0.5458 \\
\hline & & 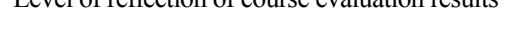 & Non-accredited & 5.09 & 0.12 & 0.01 & 0.0450 \\
\hline & Number of faculty members & & Accredited & 13.38 & 312 & 130 & 01971 \\
\hline & Number or racuity memoers & & Non-accredited & 10.26 & 3.12 & 1.50 & 0.1911 \\
\hline $\begin{array}{l}\text { Number of } \\
\text { faculty }\end{array}$ & Department personnel* & & Accredited & 79.96 & 19.71 & 2.20 & 00318 \\
\hline $\begin{array}{l}\text { faculty } \\
\text { members }\end{array}$ & Department personnel* & & Non-accredited & 60.25 & 19.71 & 2.20 & 0.0318 \\
\hline & Class hours per week & & Accredited & 9.95 & -070 & -158 & 01261 \\
\hline & & & Non-accredited & 10.66 & -0.10 & -1.00 & 0.1201 \\
\hline Program & & Ability to apply the knowledge of mathematics, & Accredited & 4.98 & 021 & 101 & 03149 \\
\hline $\begin{array}{c}\text { outcomes and } \\
\text { assessment }\end{array}$ & & science, and engineering science & Non-accredited & 4.77 & 0.21 & 1.01 & 0.3149 \\
\hline & & Ability to internret and analvze data & Accredited & 5.20 & 028 & 158 & 01162 \\
\hline & & Ability to interpret and analyze data & Non-accredited & 4.92 & 0.28 & 1.58 & 0.1162 \\
\hline & & Ability to design systems, components, and & Accredited & 5.18 & 041 & 233 & 00215 \\
\hline & & processes* & Non-accredited & 4.77 & 0.71 & 2.00 & 0.0210 \\
\hline & & Ability to identify, formulate, and solve engi- & Accredited & 5.04 & 0.20 & 1.13 & 0.2608 \\
\hline & & neering problems & Non-accredited & 4.85 & 0.20 & & \\
\hline & & Ability to use up-to-date techniques, skills, and & Accredited & 5.42 & 041 & 261 & 0.0104 \\
\hline & & engineering tools* & Non-accredited & 5.02 & 0.41 & 2.01 & 0.0104 \\
\hline & & Ability to function in multi-discinlinary teams* & Accredited & 5.53 & 0.55 & 3.00 & 0.0034 \\
\hline & & & Non-accredited & 4.98 & & & \\
\hline
\end{tabular}




\begin{tabular}{|c|c|c|c|c|c|c|c|}
\hline & & \multirow{2}{*}{ Ability to communicate effectively* } & Accredited & 5.51 & \multirow{2}{*}{0.57} & \multirow{2}{*}{2.97} & \multirow{2}{*}{0.0037} \\
\hline & & & Non-accredited & 4.94 & & & \\
\hline & & \multirow{2}{*}{$\begin{array}{l}\text { Recognition of the need for, and an ability to } \\
\text { engage in life-long learning }\end{array}$} & Accredited & 4.49 & \multirow{2}{*}{0.17} & \multirow{2}{*}{0.90} & \multirow{2}{*}{0.3701} \\
\hline & & & Non-accredited & 4.32 & & & \\
\hline & & \multirow{2}{*}{$\begin{array}{l}\text { Ability to understand the impact of engineering } \\
\text { solutions in a global and social context }\end{array}$} & Accredited & 4.67 & \multirow{2}{*}{0.27} & \multirow{2}{*}{1.37} & \multirow{2}{*}{0.1751} \\
\hline & & & Non-accredited & 4.40 & & & \\
\hline & & \multirow{2}{*}{$\begin{array}{l}\text { Knowledge of contemporary issues in the soci- } \\
\text { ety, economy, environment, and law }\end{array}$} & Accredited & 4.60 & \multirow{2}{*}{0.37} & \multirow{2}{*}{1.82} & \multirow{2}{*}{0.0717} \\
\hline & & & Non-accredited & 4.23 & & & \\
\hline & & \multirow{2}{*}{$\begin{array}{l}\text { Understanding of professional and ethical re- } \\
\text { sponsibilities* }\end{array}$} & Accredited & 4.98 & \multirow{2}{*}{0.59} & \multirow{2}{*}{-2.76} & \multirow{2}{*}{0.0067} \\
\hline & & & Non-accredited & 4.38 & & & \\
\hline & & \multirow{2}{*}{$\begin{array}{l}\text { Ability to understand other cultures and engage } \\
\text { in international collaboration }\end{array}$} & Accredited & 4.64 & \multirow{2}{*}{0.38} & 190 & 0.0603 \\
\hline & & & Non-accredited & 4.26 & & 1.90 & 0.0003 \\
\hline & & Ability to think creatively* & Accredited & 5.13 & 038 & 231 & 0.0226 \\
\hline & & Aomity to timik creativery & Non-accredited & 4.75 & 0.50 & 2.91 & 0.0220 \\
\hline & Proportion of improvement & & Accredited & 6.50 & 0.69 & 169 & 0.0940 \\
\hline & over former evaluation results & & Non-accredited & 5.81 & 0.09 & 1.09 & 0.0940 \\
\hline & & Consistency of continuous quality improvement & Accredited & 4.65 & 0.42 & 170 & 00916 \\
\hline & & (CQI) system & Non-accredited & 4.23 & 0.42 & 1.10 & 0.0910 \\
\hline & Number of program internal & & Accredited & 2.04 & 0.55 & 17 & 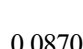 \\
\hline & evaluations & & Non-accredited & 1.49 & 0.55 & 1.1 & $0.00 / 0$ \\
\hline Program and & Number of program external & & Accredited & 1.17 & 028 & 204 & 00436 \\
\hline $\begin{array}{l}\text { educational } \\
\text { improvement }\end{array}$ & evaluations* & & Non-accredited & 0.89 & 0.28 & 2.04 & 0.0450 \\
\hline & Number of evaluations for & & Accredited & 1.19 & 021 & 138 & 01707 \\
\hline & objectives & & Non-accredited & 0.99 & & 1.50 & $0.1 / 01$ \\
\hline & & Level of internal program compared with exter- & Accredited & 4.73 & 0.50 & 227 & 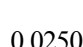 \\
\hline & & nal program* & Non-accredited & 4.23 & 0.50 & 2.21 & 0.0250 \\
\hline & & Level of data and documents management* & Accredited & 5.04 & 0.64 & 268 & 0.0084 \\
\hline & & & Non-accredited & 4.40 & & & \\
\hline & Percentage of students em- & & Accredited & 7.19 & 001 & 003 & 09775 \\
\hline & ployed & & Non-accredited & 7.18 & 0.01 & 0.05 & 0.9113 \\
\hline Output & Percentage of students who go & & Accredited & 2.05 & 0.14 & 041 & 0.6793 \\
\hline & $\begin{array}{l}\text { on to a higher stage of educa- } \\
\text { tion }\end{array}$ & & Non-accredited & 1.91 & 0.14 & 0.41 & $0.0 / 93$ \\
\hline & & Improvement in level of departmental aware- & Accredited & 4.86 & 041 & 226 & 00257 \\
\hline & & ness* & Non-accredited & 4.45 & & & \\
\hline & & Level of training expertise & Accredited & 4.89 & 0.26 & 152 & 0.1308 \\
\hline Outcome & & Lever or training expertise & Non-accredited & 4.63 & 0.20 & & 0.1500 \\
\hline Conconte & & Improvement in level of curriculum and educa- & Accredited & 5.09 & 055 & 315 & 00021 \\
\hline & & tional programs* & Non-accredited & 4.54 & 0.55 & 3.15 & 0.0021 \\
\hline & & Level of increment of research interaction with & Accredited & 4.25 & 016 & 0.68 & 0.4990 \\
\hline & & industry & Non-accredited & 4.09 & 0.10 & 0.00 & 0.4990 \\
\hline & & Contribution to the nercention of enoineering & Accredited & 5.07 & 038 & 187 & 00714 \\
\hline & & Contribution to the percepuon or engineering & Non-accredited & 4.69 & 0.50 & 1.02 & 0.0714 \\
\hline Imnect & & Jevel of contribution to national orowth & Accredited & 5.20 & 025 & 120 & 02313 \\
\hline Impact & & Level of contribution to national growth & Non-accredited & 4.95 & 025 & 1.20 & 0.2313 \\
\hline & & Advancement of engineering and science & Accredited & 4.91 & -012 & -0.46 & 06492 \\
\hline & & & Non-accredited & 5.03 & & & \\
\hline
\end{tabular}

CSF: critical success factor, KPI: key performance indicator.

$* \mathrm{p}<0.05$. 


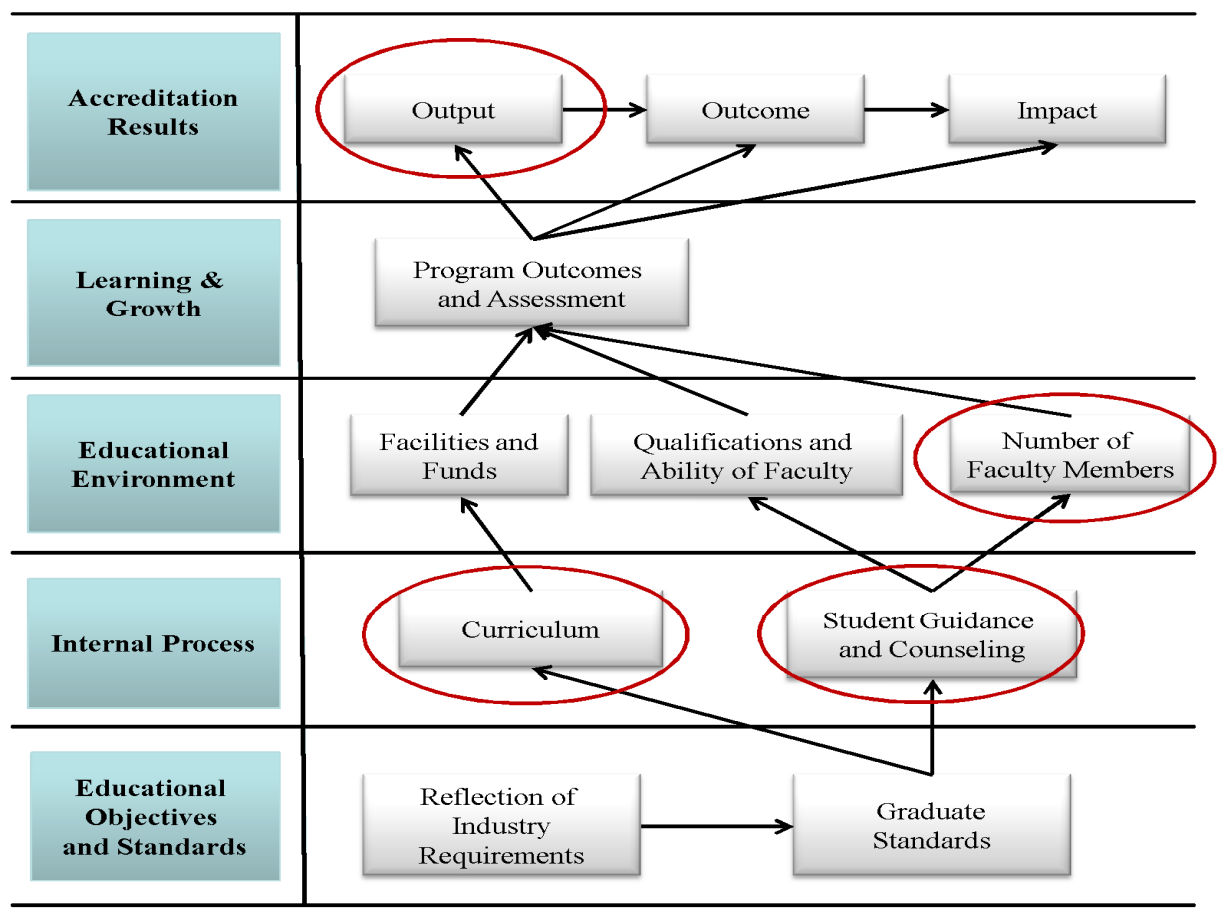

Figure 2. The strategy map for graduates.

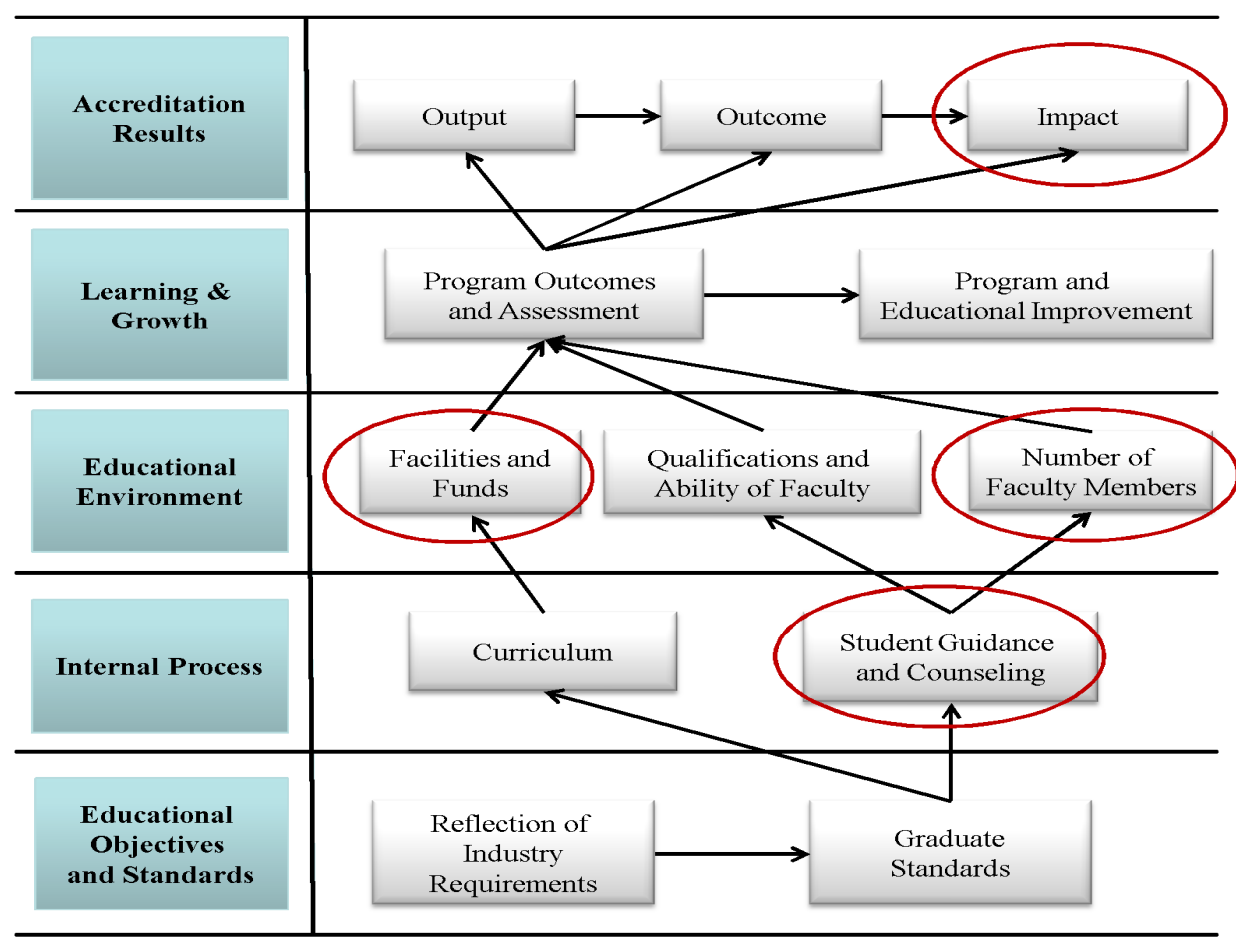

Figure 3. The strategy map for faculty.

Professors from both accredited and non-accredited programs did not see significant difference in both the percentage of employment and the percentage of entrance into a graduate school. In addition, all KPIs of impact are not significantly different. That is, professors view that there are no significant contribution difference due to engineering education accreditation to country and society. In professors' opinion, significant KPIs are the improvement in departmental awareness and the improvement in the curriculum and educational programs. 
Figure 3 shows the strategy map for faculty. The circles displayed in Figure 3 indicate the CSFs which have both insignificant KPIs and negative values. The negative values in average KPI indicate that the average scores that professors from accredited programs evaluated were higher than those from accredited programs. In professors' perspective, "student guidance and counseling", "facilities and funds", "number of faculty members" and "impact" should be improved in order to gain better accreditation effects.

\subsection{Industry}

In industry, we investigate whether employers feel differences between accredited programs and non accredited programs in terms of the KPIs.

Since the questionnaires for industry managers were made to compare employees graduated from accredited program with those from non-accredited program (refer to Appendix A), the target respondents were needed to be the managers who have experienced both employees graduated from accredited program and the other. This is a different feature of industry survey from the others. For the purpose of comparison of both types of employees, we conducted a paired t-test for the difference observed from a pair of employees from each group by each manager.

To carry out the paired t-test, we converted the 7point scale into a scale ranging between -3 to +3 with 0 indicating no difference between the two groups. If the result of the paired t-test is positive $(+)$, it is interpreted that the new employees graduated from accredited program were rated better. If the result of the paired t-test is negative $(-)$, it is interpreted that the new employees graduated from non-accredited program are better. The results of the paired comparison t-test are shown in Table 5 .

At a significance level of 5\%, most KPIs showed a significant difference between employees who graduated from accredited program and non-accredited program except for the understanding of professional and ethical responsibilities. Except for these two, the employees who graduated from accredited program were rated higher than employees from non-accredited program. Especially, the employees who graduated from an accredited program were evaluated to be excellent in the

Table 5. The results of the paired comparison t-test for industry

\begin{tabular}{|c|c|c|c|c|}
\hline \multirow{2}{*}{ CSF } & KPI & \multirow{2}{*}{ Mean } & \multirow{2}{*}{$\mathrm{t}$} & \multirow{2}{*}{ p-value } \\
\hline & Quantitative indices & & & \\
\hline \multirow{7}{*}{$\begin{array}{l}\text { Reflection of } \\
\text { industry } \\
\text { requirements }\end{array}$} & Level of fundamental knowledge* & 0.45 & 3.60 & 0.0005 \\
\hline & Level of expert knowledge* & 0.43 & 3.46 & 0.0008 \\
\hline & Ability to use equipment* & 1.11 & 8.33 & $<0.0001$ \\
\hline & Technical planning and management* & 0.40 & 3.21 & 0.0018 \\
\hline & Level of quality control knowledge* & 0.49 & 4.33 & $<0.0001$ \\
\hline & Problem solving ability* & 0.68 & 5.81 & $<0.0001$ \\
\hline & Communication and teamwork ability* & 0.61 & 5.46 & $<0.0001$ \\
\hline \multirow{14}{*}{$\begin{array}{c}\text { Program } \\
\text { outcomes and } \\
\text { assessment }\end{array}$} & Ability to apply mathematics, science, and engineering science knowledge* & 1.17 & 9.83 & $<0.0001$ \\
\hline & Ability to interpret and analyze data* & 0.89 & 8.45 & $<0.0001$ \\
\hline & Ability to design systems, components, and processes* & 0.32 & 2.86 & 0.0051 \\
\hline & Ability to identify, formulate, and solve engineering problems* & 0.52 & 5.00 & $<0.0001$ \\
\hline & Ability to use up-to-date techniques, skills, and engineering tools* & 0.79 & 7.22 & $<0.0001$ \\
\hline & Ability to function in multi-disciplinary teams* & 0.56 & 5.07 & $<0.0001$ \\
\hline & Ability to communicate effectively* & 0.82 & 7.36 & $<0.0001$ \\
\hline & Recognition of the need for, and an ability to engage in life-long learning* & 0.94 & 8.28 & $<0.0001$ \\
\hline & $\begin{array}{l}\text { Ability to understand the impact of engineering solutions in a global and social } \\
\text { context* }\end{array}$ & 0.74 & 7.25 & $<0.0001$ \\
\hline & $\begin{array}{l}\text { Knowledge of contemporary issues in the society, economy, environment, and } \\
\text { law* }\end{array}$ & 0.69 & 6.13 & $<0.0001$ \\
\hline & Understanding of professional and ethical responsibilities & 0.25 & 1.96 & 0.0526 \\
\hline & Ability to understand other cultures and engage in international collaboration* & 0.63 & 5.64 & $<0.0001$ \\
\hline & Ability to think creatively* & 0.78 & 7.50 & $<0.0001$ \\
\hline & Level of self-enrichment* & 0.98 & 9.06 & $<0.0001$ \\
\hline
\end{tabular}

CSF: critical success factor, KPI: key performance indicator.

$* \mathrm{p}<0.05$. 
ability to apply mathematics, science, and engineering science knowledge.

Additionally, we check that the contribution of the engineering education accreditation programs in terms of accreditation results, such as output, outcome, and impact using chi-square test. To perform the chi-square test, we classified industry respondents of each KPI into three groups: 1-3 points represent a low contribution level, 4 points represent a middle contribution level, and 5-7 points represent a high contribution level. The results of the chi-square test are shown in Table 6.

At a significance level of 5\%, the results of the chisquare test indicate that all KPIs in terms of output, outcome, and impact showed a significant difference in the contribution level. Approximately $50 \%$ of industry respondents answered that engineering education accreditation program contributes to industry, country, and society.

\section{CONCLUDING REMARKS}

In this study, we developed the performance evaluation indices and the strategy map based on the BSC concept and evaluated the effects of engineering education accreditation in Korea. There were many studies which attempted to assess the accreditation. However, this study is the first to apply the BSC to comparing the accredited program to non-accredited ones in Korea.

While EC2000 study focused only on criterion 3(a$\mathrm{k})$, we consider all the criteria of engineering accreditation: quality and learning outcomes of students, educational objectives of program, program outcome and as- sessment that covers criterion 3(a-k) of ABET, professional component, faculty, facilities and funds, and program criteria. With such criteria and specific measures, we proposed performance evaluation indices for engineering education accreditation in a BSC framework.

To evaluate the effect of engineering education accreditation of ABEEK, we applied the proposed indicators to graduates, faculty, and industry employers to determine if there are significant differences between accredited and non-accredited programs.

The test results indicated that for graduates, 35 of 42 KPIs showed significant differences between accredited and non-accredited programs. The adequacy of graduate standards showed the biggest difference between the two groups. Counseling satisfaction also showed a significantly large difference.

For faculty, only 14 KPIs showed significant differences between accredited and non-accredited programs. For those 14 KPIs, overall, the accredited group had a higher average score than the non-accredited group. However, in the case of "facilities and funds", the result was the opposite. That is, the average scores of nonaccredited group were higher than accredited group in the aspects of laboratories, equipment, facilities, and funding. To overcome these unexpected results, the institutes having accredited programs need to strengthen education facilities and funding support.

Industry evaluated that for almost all KPIs employees graduated from accredited program are better than those from non-accredited program. This improvement was seen especially in the ability to apply mathematics, science, and engineering science knowledge, and the ability to use up-to-date techniques, skills, and engineer-

Table 6. The results of the chi-square test for industry

\begin{tabular}{|c|c|c|c|c|c|}
\hline CSF & KPI & Contribution level & $\mathrm{N}$ & $\chi^{2}$ & p-value \\
\hline \multirow{3}{*}{ Output } & \multirow{3}{*}{ Contribution of new employee's educational program* } & Low & 13 & \multirow{3}{*}{19.34} & \multirow{3}{*}{$<0.0001$} \\
\hline & & Middle & 40 & & \\
\hline & & High & 47 & & \\
\hline \multirow{3}{*}{ Outcome } & \multirow{3}{*}{ Contribution of improvement of job performance* } & Low & 13 & \multirow{3}{*}{21.98} & \multirow{3}{*}{$<0.0001$} \\
\hline & & Middle & 36 & & \\
\hline & & High & 51 & & \\
\hline \multirow{9}{*}{ Impact } & \multirow{3}{*}{ Contribution to the perception of engineering* } & Low & 13 & \multirow{3}{*}{18.98} & \multirow{3}{*}{$<0.0001$} \\
\hline & & Middle & 41 & & \\
\hline & & High & 46 & & \\
\hline & \multirow{3}{*}{ Contribution level of national growth* } & Low & 16 & \multirow{3}{*}{19.52} & \multirow{3}{*}{$<0.0001$} \\
\hline & & Middle & 32 & & \\
\hline & & High & 52 & & \\
\hline & \multirow{3}{*}{ Advancement of engineering and science* } & Low & 16 & \multirow{3}{*}{19.52} & \multirow{3}{*}{$<0.0001$} \\
\hline & & Middle & 32 & & \\
\hline & & High & 52 & & \\
\hline
\end{tabular}

CSF: critical success factor, KPI: key performance indicator.

$* \mathrm{p}<0.05$. 
ing tools. In the EC2000 study, however, the employers reported that "use math, science, and technical skills", "apply problem-solving skills" and "understand of the environmental contexts/constraints" have declined from 1994 to 2004, while the other two of the five dimensions reflecting criterion $3(\mathrm{a}-\mathrm{k})$, such as "learn, grow, and adapt" and "communicate and work in teams" have increased (Lattuca et al., 2006).

Although the present study was fundamentally based on EC2000 study, it looked at more on the difference between the accredited group and the non-accredited group while EC2000 study considered the engineering change according to implementation of outcomes based EC2000 accreditation criteria. Our study also shows the differences in factors appeared in the entire circumstance of accreditation by adopting the BSC approach and strategy map.

That is, the strategy maps are given to show the causal relationship between CSFs. By reviewing the paths on strategy maps in detail, we found some areas that need to be improved for enhancing our accreditation framework. For example, in the strategy map for graduates, "curriculum," "student guidance and counseling," "number of faculty members," and "output" have at least one insignificant KPI. Thus, for the future improvement of our accreditation framework, these four CSFs that have at least one insignificant KPI should be improved. One of the improved actions that the accredited program easily can conduct is the group counseling. In many previous studies, the counseling has been introduced as one of the best solutions for reducing the gap of student achievement or learning performance (Campbell and Brigman, 2005). Most education institutes have already been doing counseling. However, the participation rate of the students to counseling is very low in many institutes of Korea. Furthermore, the counseling usually has been conducted at individual level, for example, one student with a professor assigned. For the specific future action plan to overcome the previously mentioned problems, such as student guidance and counseling, we suggest the group counseling proposed by Campbell and Brigman (2005). On the other hand, some other areas which are detected as insignificant on the strategy maps are related to institutional capability. For instance, the facilities and number of faculty members are related with the size of institutes and their budget to be used at individual institutional level. In such areas, institutions should make a proper effort to improve the performance of the corresponding areas.

We expect that the framework suggested by our study can contribute to continuous improvement of engineering education in Korea. By improving the areas of some KPIs that are statistically insignificant, universities can educate and train better engineers having practical competence and quality. Furthermore, the national science and technology can be improved. Our proposed performance indicators can also be used as the basis for other countries which are in the process of assessing their engineering accreditation. Additionally, we think that proposed concept of strategy map, CSFs, and KPIs can be used in other disciplines such as management and science when some contents are revised. Further research is necessary to determine the causal relationships among the indicators (Lee et al., 2007). Furthermore, research has to be done to determine weights of indicators. Another limitation of this research is that we did not consider the effect of the reputation of the universities. High quality students want to enroll in a university which has high reputation. Engineering education accreditation would have influence on the reputation of university. Therefore, in further study, the researcher needs to compare universities at the same level to analyze the effect of engineering education accreditation. In addition, the results of this paper are based on respondents. Therefore, in order to increase the reliability and validity of results, further study needs to increase the response rate.

\section{ACKNOWLEDGMENTS}

This work was supported by the National Research Foundation of Korea (NRF) grant funded by the Korea government (2013R1A2A1A09004699).

\section{REFERENCES}

Accreditation Board for Engineering Education of Korea (2005), Criteria for accrediting engineering programs (KEC2005), http://www.abeek.or.kr/htmls kr/en/data/KEC2005_120329(rev8).pdf.

Ale Ebrahim, N., Rashid, A., Hanim, S., Ahmed, S., and Taha, Z. (2011), The effectiveness of virtual R\&D teams in SMEs: experiences of Malaysian SMEs, Industrial Engineering and Management Systems, 10(2), 109-114.

Bobillo, F., Delgado, M., Gomez-Romero, J., and Lopez, E. (2009), A semantic fuzzy expert system for a fuzzy balanced scorecard, Expert Systems with Applications, 36(1), 423-433.

Bull, S., Gardner, P., Ahmad, N., Ting, J., and Clarke, B. (2009), Use and trust of simple independent open learner models to support learning within and across courses. In: Houben, G. J. et al. (eds.), User Modeling, Adaptation, and Personalization, Springer, Heidelberg, Germany, 42-53.

Bullen, F. and Silverstein, J. (2005), Linking local attributes to global accreditation, Proceedings of the 35th Annual Conference Frontiers in Education, Indianapolis, IN, F2D-1.

Butler, A., Letza, S. R., and Neale, B. (1997), Linking the balanced scorecard to strategy, Long Range Planning, 30(2), 242-153. 
Campbell, C. A. and Brigman, G. (2005), Closing the achievement gap: a structured approach to group counseling, Journal for Specialists in Group Work, 30(1), 67-82.

Carman, J. G. (2007), Evaluation practice among community-based organizations research into the reality, American Journal of Evaluation, 28(1), 60-75.

Chen, L. S. (2011), Special issue section: using TRIZ techniques to new product function development of smart phones, Industrial Engineering and Management Systems, 10(3), 179-184.

Chen, M. Y., Huang, M. J., and Cheng, Y. C. (2009), Measuring knowledge management performance using a competitive perspective: an empirical study, Expert Systems with Applications, 36(4), 8449-8459.

Chen, S. H., Yang, C. C., and Shiau, J. Y. (2006), The application of balanced scorecard in the performance evaluation of higher education, The TQM Magazine, 18(2), 190-205.

Colbeck, C. L., Campbell, S. E., and Bjorklund, S. A. (2000), Grouping in the dark: what college students learn from group projects, Journal of Higher Education, 71(1), 60-83.

Engineering Council UK (2007), UK-SPEC baseline project, ECUK Final Report 37, Engineering Council UK, London.

Felder, R. M. and Brent, R. (2003), Designing and teaching courses to satisfy the ABET engineering criteria, Journal of Engineering Education, 92(1), 725.

Felder, R. M. and Hadgraft, R. G. (2013), Educational practice and educational research in engineering: partners, antagonists, or ships passing in the night? Journal of Engineering Education, 102(3), 339-345.

Geiger, R. L. (1990), Organized research units: their role in the development of university research, $J_{O}$ urnal of Higher Education, 61(1), 1-19.

Halbo, L., Lund, K., and Froystein, H. A. (2005), Quality management education over the internet, $A c$ creditation and Quality Assurance, 10(3), 116-120.

Huang, H. C. (2009), Designing a knowledge-based system for strategic planning: a balanced scorecard perspective, Expert Systems with Applications, 36 (1), 209-218.

Johnson, K., Bryant, D., Rockwell, D., Moore, M., Straub, B. W., Cummings, P., and Wilson, C. (1999), Obtaining active parental consent for evaluation research: a case study, American Journal of Evaluation, 20(2), 239-249.

Kaplan, R. and Norton, D. P. (2013), Alignment: Using the Balanced Scorecard to Create Corporate Synergies, Harvard Business School Press, Boston, MA.

Kaplan, R. S. and Norton, D. P. (1992), The balanced scorecard: measures that drive performance, Harvard Business Review, 70(1), 71-79.
Kaplan, R. S. and Norton, D. P. (1996), Using the balanced scorecard as a strategic management system, Harvard Business Review, 74(1), 75-85.

Kaplan, R. S. and Norton, D. P. (2001a), The StrategyFocused Organization: How Balanced Scorecard Companies Thrive in the New Business Environment, Harvard Business School Press, Boston. MA.

Kaplan, R. S. and Norton, D. P. (2001b), Transforming the balanced scorecard from performance measurement to strategic management: part I, Accounting Horizons, 15(1), 87-104.

Kaplan, R. S. and Norton, D. P. (2001c), Transforming the balanced scorecard from performance measurement to strategic management: part II, Accounting Horizons, 15(2), 147-160.

Kaplan, R. S. and Norton, D. P. (2004), Strategy Maps: Converting Intangible Assets into Tangible Outcomes, Harvard Business School Press, Boston, MA.

Lattuca, L. R., Strauss, L. C., and Volkwein, J. F. (2007), Getting in sync: faculty and employer perceptions from the national study of EC2000, International Journal of Engineering Education, 22(3), 460-469.

Lattuca, L. R., Terenzini, P. T., and Volkwein, J. F. (2006), Engineering Change: A Study of the Impact of EC2000, ABET Inc., Baltimore, MD.

Lawrence, S. and Sharma, U. (2002), Commodification of education and academic LABOUR-using the balanced scorecard in a university setting, Critical Perspectives on Accounting, 13(5-6), 661-677.

Lee, J. H. and Walsh, D. J. (2004), Quality in early childhood programs: reflections from program evaluation practices, American Journal of Evaluation, 25(3), 351-373.

Lee, S. F., Lo, K. K., Leung, R. F., and Ko, A. S. O. (2000), Strategy formulation framework for vocational education: integrating SWOT analysis, balanced scorecard, QFD methodology and MBNQA education criteria, Managerial Auditing Journal, 15(8), 407-423.

Lee, Y. F., Altschuld, J. W., and Hung, H. L. (2008), Practices and challenges in educational program evaluation in the Asia-Pacific region: results of a delphi study, Evaluation and Program Planning, 31(4), 368-375.

Li, Q., McCoach, D. B., Swaminathan, H., and Tang, J. (2008), Development of an instrument to measure perspectives of engineering education among college students, Journal of Engineering Education, 97(1), 47-56.

Murphy, T. E., Gaughan, M., Hume, R., and Moore, S. G. (2010), College graduation rates for minority students in a selective technical university: will participation in a summer bridge program contribute to success? Educational Evaluation and Policy Analysis, 32(1), 70-83.

Olve, N. G., Roy, J., and Wetter, M. (1999), Performance Drivers: A Practical Guide to Using The Bal- 
anced Scorecard, John Wiley and Sons, New York, NY.

Patil, A. and Codner, G. (2007), Accreditation of engineering education: review, observations and proposal for global accreditation, European Journal of Engineering Education, 32(6), 639-651.

Perrin, B. (1998), Effective use and misuse of performance measurement, American Journal of Evaluation, 19(3), 367-379.

Politis, Y. and Siskos, Y. (2004), Multicriteria methodology for the evaluation of a Greek engineering department, European Journal of Operational Research, 156(1), 223-240.

Porter, A. L., Roessner, J. D., Oliver, S., and Johnson, D. (2006), A systems model of innovation processes in university STEM education, Journal of Engineering Education, 95(1), 13-24.

Qin, S. Y., Atkins, A. S., and Yu, H. (2013), Balanced scorecard approach to evaluate business performance measurement using web tools in e-Tourism, International Journal of Computing Science and Communication Technologies, 5(2), 822-828.

Roach, A. T. and Elliott, S. N. (2006), The influence of access to general education curriculum on alternate assessment performance of students with significant cognitive disabilities, Educational Evaluation and Policy Analysis, 28(2), 181-194.

Siskos, Y., Grigoroudis, E., Krassadaki, E., and Matsatsinis, N. (2007), A multicriteria accreditation system for information technology skills and qualifications, European Journal of Operational Research, 182(2), 867-885.

Sohn, S. Y. and Ju, Y. H. (2010a), Conjoint analysis for recruiting high quality students for college education, Expert Systems with Applications, 37(5), 37773783.

Sohn, S. Y. and Ju, Y. H. (2010b), Perceptions of engineering among Korean youth, International Journal of Engineering Education, 26(1), 205-217.

Sohn, S. Y. and Ju, Y. H. (2011), Design and implementation of youth engineering adventure program in Korea, International Journal of Engineering Edu- cation, 27(5), 1107-1116.

Sohn, S. Y. and Kim, Y. (2012), DEA based multi-period evaluation system for research in academia, Expert Systems with Applications, 39(9), 8274-8278.

Sohn, S. Y., Joo, Y. G., and Han, H. K. (2007), Structural equation model for the evaluation of national funding on R\&D project of SMEs in consideration with MBNQA criteria, Evaluation and Program Planning, 30(1), 10-20.

Stiles, L. J. (1968), Interdisciplinary accountability for teacher education: the developing partnership between academic and professional scholars is only a beginning, Journal of Higher Education, 39(1), 2331.

Strauss, L. C. and Terenzini, P. T. (2005), Assessing student performance on EC2000 Criterion 3.a-k, Proceedings of the 2005 American Society for Engineering Education Annual Conference and Exposition, Portland, OR, 1-17.

Stronge, J. H. and Helm, V. M. (1992), A performance evaluation system for professional support personnel, Educational Evaluation and Policy Analysis, 14(2), 175-180.

Sutherland, T. (2000), Designing and implementing an academic scorecard, Accounting Education News, (summer), 11-13.

Umashankar, V. and Dutta, K. (2007), Balanced scorecards in managing higher education institutions: an Indian perspective, International Journal of Educational Management, 21(1), 54-67.

van Merode, G. G., Groothuis, S., and Goldschmidt, H. J. M. (1999), Workflow management: changing your organization through simulation, Accreditation and Quality Assurance, 4(9-10), 438-442.

Vogt, W. (2001), The German perspective of using the EFQM model in medical laboratories, Accreditation and Quality Assurance, 6(9-10), 396-401.

Wiratmadja, I. I., Govindaraju, R., and Setiawati, E. (2011), Analysing the influence of technology on the business performance of rattan processing SMEs in South Kalimantan, Industrial Engineering and Management Systems, 10(2), 104-108. 


\section{Appendix A. Examples: parts of survey questionnaires}

The survey questionnaires for the graduates

$1=$ strongly disagree/absolutely not/very poor

$4=$ average/neutral

$7=$ strongly agree/excellent/very much so

\begin{tabular}{|c|c|c|c|c|c|c|c|}
\hline Questions as KPIs & \multicolumn{7}{|c|}{ Answers } \\
\hline Have you received counseling from your department professors? & \multicolumn{7}{|c|}{ Yes/No } \\
\hline $\begin{array}{l}\text { If you have received counseling, how many times did you receive counseling during a } \\
\text { semester? } \\
\text { (If you have not received counseling, you should answer “0”.) }\end{array}$ & \multicolumn{7}{|c|}{ Time(s) } \\
\hline Have you completed more than 60 credits in your major subjects? & \multicolumn{7}{|c|}{ Yes/No } \\
\hline $\begin{array}{l}\text { Did your ability to apply mathematics, science, and engineering science knowledge } \\
\text { increase after you had taken courses/curriculum of your program? }\end{array}$ & 1 & 2 & 3 & 4 & 5 & 6 & 7 \\
\hline $\begin{array}{l}\text { Did your ability to identify, formulate, and solve engineering problems increase after you } \\
\text { had completed courses/curriculum of your program? }\end{array}$ & 1 & 2 & 3 & 4 & 5 & 6 & 7 \\
\hline $\begin{array}{l}\text { Did your ability to use up-to-date techniques, skills, and engineering tools increase after } \\
\text { you had completed courses/curriculum of your program? }\end{array}$ & 1 & 2 & 3 & 4 & 5 & 6 & 7 \\
\hline $\begin{array}{l}\text { Do you think that the engineering education policy and system such as the engineering } \\
\text { education accreditation have effect on advancement of engineering and science? }\end{array}$ & 1 & 2 & 3 & 4 & 5 & 6 & 7 \\
\hline
\end{tabular}

The survey questionnaires for the faculty

\begin{tabular}{|c|c|c|c|c|c|c|c|}
\hline Questions as KPIs & \multicolumn{7}{|c|}{ Answers } \\
\hline Do you think that your department's graduate standards are adequate? & 1 & 2 & 3 & 4 & 5 & 6 & 7 \\
\hline $\begin{array}{l}\text { Do you think that your department's curriculum organization is adequate to train } \\
\text { professional engineers? }\end{array}$ & 1 & 2 & 3 & 4 & 5 & 6 & 7 \\
\hline Are you satisfied with administrative performance? & 1 & 2 & 3 & 4 & 5 & 6 & 7 \\
\hline Do you think that your department's funds and administrative support are adequate? & 1 & 2 & 3 & 4 & 5 & 6 & 7 \\
\hline How long have you been teaching? & \multicolumn{7}{|c|}{ Year(s) } \\
\hline Do you reflect your course evaluation results? & 1 & 2 & 3 & 4 & 5 & 6 & 7 \\
\hline How many students are in your department? (average per grade) & \multicolumn{7}{|c|}{ Persons } \\
\hline $\begin{array}{l}\text { Do you think that students' ability to interpret and analyze data increased after they } \\
\text { had completed courses/curriculum of the department program? }\end{array}$ & 1 & 2 & 3 & 4 & 5 & 6 & 7 \\
\hline $\begin{array}{l}\text { Do you think that students' ability to think creatively increased after they had } \\
\text { completed courses/curriculum of the department program? }\end{array}$ & 1 & 2 & 3 & 4 & 5 & 6 & 7 \\
\hline How many times does your department have external evaluation for the program annually? & \multicolumn{7}{|c|}{ Time(s) } \\
\hline Do you think that your department's awareness has been improved? & 1 & 2 & 3 & 4 & 5 & 6 & 7 \\
\hline
\end{tabular}

The survey questionnaires for the industry

\begin{tabular}{|c|c|c|c|c|c|c|c|}
\hline Questions as KPIs & & & & hSW & & & \\
\hline $\begin{array}{l}\text { Do you think that new employees graduated from accredited programs have better problem } \\
\text { solving ability than new employees graduated from non-accredited programs? }\end{array}$ & 1 & 2 & 3 & 4 & 5 & 6 & 7 \\
\hline $\begin{array}{l}\text { Do you think that new employees graduated from accredited programs have better commu- } \\
\text { nication and teamwork ability than new employees graduated from non-accredited pro- } \\
\text { grams? }\end{array}$ & 1 & 2 & 3 & 4 & 5 & 6 & 7 \\
\hline $\begin{array}{l}\text { Do you think that new employees graduated from accredited programs have better under- } \\
\text { standing of professional and ethical responsibilities than new employees graduated from } \\
\text { non-accredited programs? }\end{array}$ & 1 & 2 & 3 & 4 & 5 & 6 & 7 \\
\hline $\begin{array}{l}\text { Do you think that new employees graduated from accredited programs have higher level of } \\
\text { self-enrichment than new employees graduated from non-accredited programs? }\end{array}$ & 1 & 2 & 3 & 4 & 5 & 6 & 7 \\
\hline $\begin{array}{l}\text { Do you think that the engineering education policy and system such as the engineering } \\
\text { education accreditation have effect on contribution of new employee's educational program? }\end{array}$ & 1 & 2 & 3 & 4 & 5 & 6 & 7 \\
\hline $\begin{array}{l}\text { Do you think that the engineering education policy and system such as the engineering } \\
\text { education accreditation have effect on contribution of improvement of job performance? }\end{array}$ & 1 & 2 & 3 & 4 & 5 & 6 & 7 \\
\hline
\end{tabular}

